\title{
Distribution, deposition and impact of submarine mine tailings disposal on the fjord bottom in Frænfjorden, western Norway
}

Keywords:
- Submarine tailings placement
- Submarine slide
- Seafloor stability
- Seabed morphology
- Sedimentary environment
- Environmental impact
- Overpressure

Received 5. April 2019

Accepted 27. January 2020

Published online 26. May 2020

\author{
Nicole J. Baeten ${ }^{1}$, Aivo Lepland ${ }^{1}$, Reidulv B $\varnothing \mathrm{e}^{1}$, Arnstein Amundsen ${ }^{2}$, \\ Shyam Chand ${ }^{1}$ \& Oddvar Longva ${ }^{1}$. \\ ${ }^{1}$ Geological Survey of Norway (NGU), Postal Box 6315, Torgarden, 7491 Trondheim, Norway. \\ ${ }^{2}$ Omya Hustadmarmor AS, Sjøvegen 69, 6440 Elnesvågen, Norway. \\ E-mail corresponding author (Nicole J. Baeten): nicole.baeten@ngu.no
}

Frænfjorden, a fjord on the west coast of Norway, has been studied to increase our knowledge of the environmental effects of submarine tailings placement (STP). Fine-grained tailings consisting primarily of calcite are disposed of by Omya Hustadmarmor. The dataset, including multibeam echosounder data, shallow seismic, video data, grab samples and sediment cores, demonstrates that tailings are primarily deposited in an up to $2 \mathrm{~km}$-wide area with a tailings thickness of up to $20 \mathrm{~m}$. Minor quantities of tailings are spread outside the STP by tidal currents. Sediment cores show the difference in colour, mineralogy and grain size between the natural sediments and the tailings. The tailings have a white/grey colour, are very fine grained, contain high amounts of calcite and have a lower water content than the natural sediments. A series of multibeam echosounder data from 2013 to 2017 show that deposition of tailings has triggered several small gravity flows and slides. The tailings within the STP have a low stability compared to the natural sediments outside the STP because of their fine grain size and higher sensitivity, high slope angles, high sediment accumulation rates preventing normal consolidation, and loading of tailings causing overpressure in the underlying sediments.

\section{Introduction}

The mining sector is growing in parallel with societal demands for minerals (Ramirez-Llodra et al., 2015). Renewable energy sources like wind and solar infrastructure, batteries and electric vehicles all require vast amounts of mined (and recycled) minerals. The mining of these minerals is therefore a necessity for a green energy transition (e.g., NGU, 2016; Giurco et al., 2019).

Tailings are the waste produced after the extraction of the targeted material/metal from the ore through crushing/milling and separation (Vogt, 2013; Ramirez-Llodra et al., 2015). The tailings generally consist of a fine-grained slurry and can contain high proportions of the ore and processing chemicals (Ramirez-Llodra et al., 2015).

\section{(c) Copyright the authors.}

This work is licensed under a

Creative Commons Attribution
Baeten, N.J., Lepland, A., Bøe, R., Amundsen, A., Chand, S. \& Longva, O. 2020: Distribution, deposition and impact of submarine mine tailings disposal on the fjord bottom in Frænfjorden, Western Norway. Norwegian Journal of Geology 100, 202002. https://dx.doi.org/10.17850/njg100-1-3. 
Traditionally, tailings have been stored in land dams, which, however, bear a potential risk of dam failure with major environmental and societal consequences, including the devastation of large areas, the leaching of toxic chemicals and heavy metals, and acidification of waterways (Arnesen et al., 1997; Koski, 2012). Mineral resources in Norway commonly occur in coastal areas but because of the rugged terrain, storage on land is usually not an option. Moreover, the local rainy climate along the Norwegian coast may cause dams to burst if overstressed by floods (Kvassnes \& Iversen, 2013). An alternative to land storage is the disposal of tailings in the marine environment. There are three different types of tailing disposal in the sea: coastal shallow-water disposal (CTD), submarine tailing placement (STP) and deep-sea tailing placement (DSTP; Ramirez-Llodra et al., 2015). It has been argued that STP and SDTP are more stable than disposal of tailings in an impoundment or dam as the access of oxidants can be more limited in the submarine environment, thereby hindering the oxidative breakdown of minerals and release of toxic metals (Franks et al., 2011). STPs are not common worldwide, but do occur in e.g., Papua New Guinea, France, Greece, Chile, Canada, Indonesia and Turkey (Vogt, 2013; Ramirez-Llodra et al., 2015). There are 18 STPs in Norway, of which 7 were active in 2015 (Skei, 2014; Ramirez-Llodra et al., 2015).

Environmental impacts from STPs result from (1) hyper-sedimentation, (2) metal toxicity, (3) process chemicals, (4) changes in organic content, grain size and angularity, (5) sediment plumes and turbidity, and (6) materials re-suspension, upwelling and slope failure (Ramirez-Llodra et al., 2015). There is still a limited understanding of the impacts of STPs and how they can best be monitored. To fill in some of these knowledge gaps, the NYKOS (New Knowledge on Sea Disposal) project was started with objectives (1) to increase knowledge of the environmental effects of submarine deposition of fine-grained tailings and (2) to develop new sound environmental criteria and monitoring technologies that prepare for a sustainable mineral industry in Norway. These effects have been studied in different work packages focusing on; chemical processing of tailings, high-resolution bathymetric maps and substrate information, highresolution modelling of particle transport and flocculation, process chemicals in the environment, trace metals and benthic and pelagic studies (SINTEF, 2019).

In this study, we use multibeam echosounder data, results of shallow seismic profiling, seafloor video observations, grab samples and sediment cores to investigate the distribution, deposition and impact of disposed tailings in the Frænfjorden, western Norway.

\section{Bathymetry, oceanography and geological setting}

Frænfjorden is located on the west coast of Norway, in Møre og Romsdal county (Fig. 1). The fjord is approximately $12 \mathrm{~km}$ long from the Malme village in the east, where it is named Malmefjorden, to the Julsundet strait at the mouth of the fjord in the west, which connects to the larger Romsdalsfjorden (Fig. 1) (Davies \& Nepstad, 2017). Frænfjorden is up to $70 \mathrm{~m}$ deep in the western part whereas water depths are $20-40 \mathrm{~m}$ in the east. Its mouth towards Romsdalsfjorden is a shallow area with a channel that is up to $45 \mathrm{~m}$ deep. The Moaelva river enters the fjord between Malmefjorden and Elnesvågen, while the Malmedalselva river enters the fjord in Malmefjorden (Fig. 1). Both rivers are prone to flooding during snow melting in the spring and during periods of heavy rain. The main circulation within the fjord is controlled by a diurnally asymmetric, tidally driven flow with a tidal range of $2 \mathrm{~m}$ and has the anticlockwise current movement typical to western Norwegian fjords (Brooks et al., 2015; Davies \& Nepstad, 2017).

The bedrock in the Frænfjorden area consists mostly of dioritic and granitic gneisses with migmatite in some areas. Amphibolite and mica schist run through the central part of the fjord between two old thrust faults (Bryhni et al., 1989). Small patches of eclogite, periodite and pyroxenite occur east and south of the fjord. Quaternary deposits consist mostly of poorly sorted moraine with thickness up to several tens of 
metres. Glacimarine deposits occur in the northeastern part of the fjord close to Elnesvågen (Bøe, 1987; Fig. 1). Some areas have exposed bedrock at the seafloor, but basins in the south of the fjord towards Malme contain mostly postglacial clay. Marine sediments and peat/bog occur along the southern shoreline, further inland and on some of the islands (Bøe, 1987).

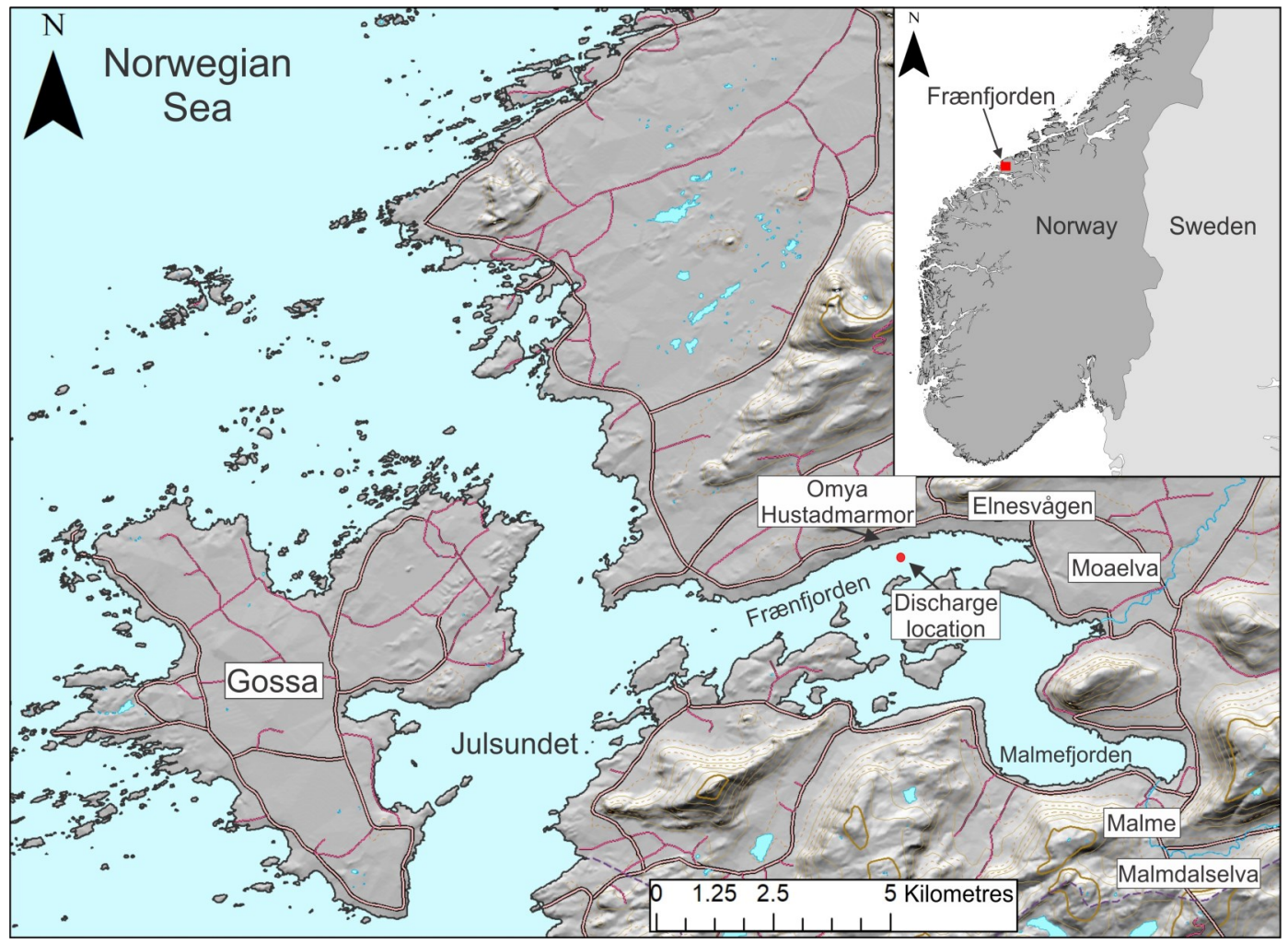

Figure 1. Location of Frænfjorden (data from Kartverket). The locations of the Omya Hustadmarmor processing plant and the discharge location are indicated.

\section{Processing of the marble, tailings composition and submarine tailings placement}

Omya Hustadmarmor processes marble supplied from mines in Eide and Fræna (Møre og Romsdal county, close to the study area) and from Brønnøysund (Nordland county, northern Norway). Raw marble is transported to the facility in Elnesvågen (Frænfjorden) by boat. The marble is ground, purified and micronized at the production/processing plant in Elnesvågen (Fig. 1). The final product is a liquid marble which is mostly used in the paper industry. The rest products, silicates and some fine calcite particles, are separated in a flotation process using chemicals. The tailings have been discharged into the fjord since 1982. The discharge takes place through extendable pipes at a distance of $390-760 \mathrm{~m}$ from the shore, at a depth of $20 \mathrm{~m}$. The pipelines are fixed to the seafloor by concrete weights (Fig. 2). The tailing disposal in Frænfjorden qualifies as an STP, with the disposal of tailings through an underwater pipeline at relatively shallow (<100 m) water depths but below the euphotic zone (Ellis \& Ellis, 1994; Shimmield et al., 2010; Vogt, 2013; Skei, 2014). The deposit area in Frænfjorden outlined in Fig. 3 will be referred to as the STP. A transition area is also indicated. The deposition in the transition area is not allowed to exceed $6 \mathrm{~mm} /$ year over a 5-year period (DNV GL, 2016). 


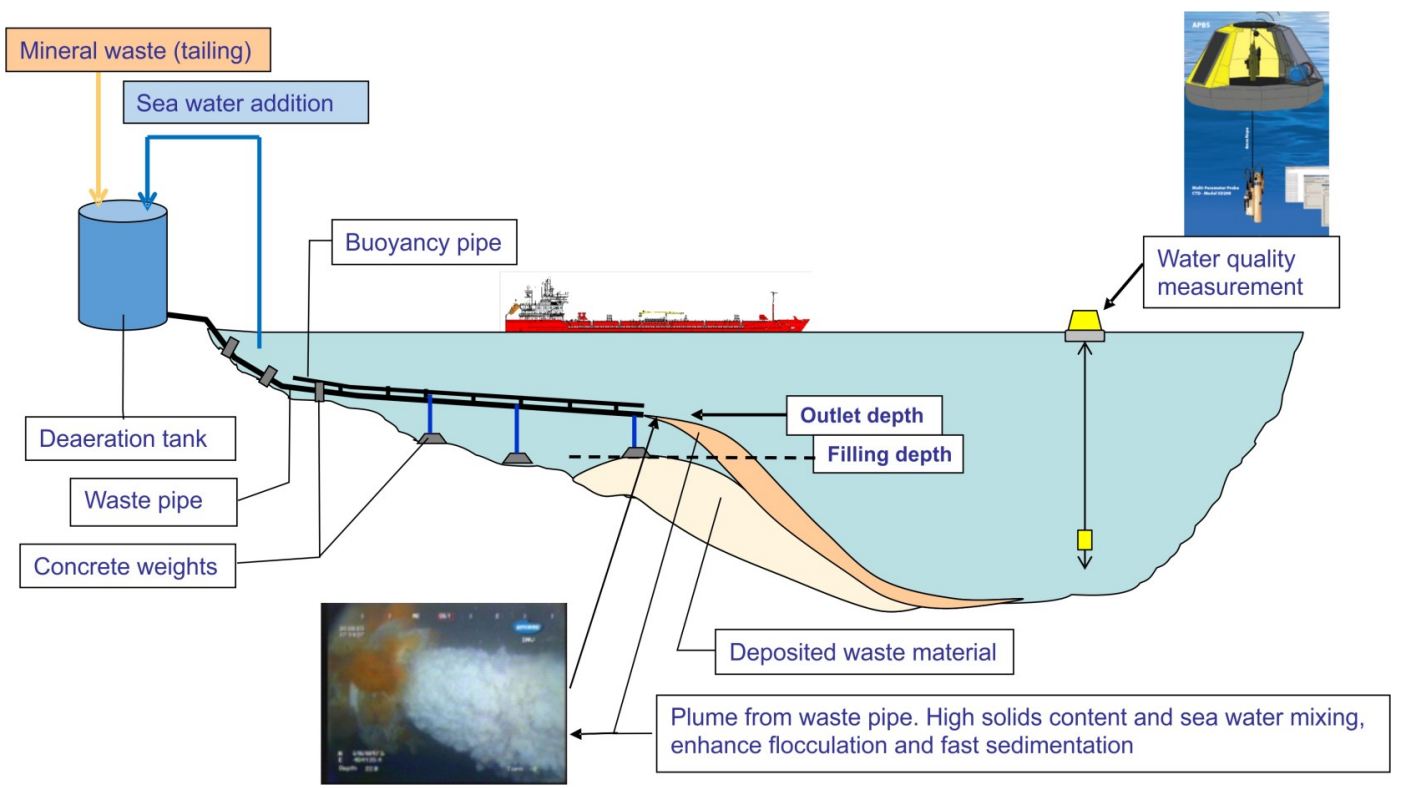

Figure 2. Principle sketch showing the deposition of tailings in Frænfjorden (from Omya Hustadmarmor).

The marble arriving at the processing plant consists of c. $96 \%$ calcite (calcium carbonate) and $4 \%$ other minerals (mainly quartz, feldspar, mica and some iron sulphide) (DNV GL, 2016). The tailings contain 50$60 \%$ calcium carbonate (DNV GL, 2018) with more than $80 \%$ of the solids finer than sand, mainly in the fractions below $20 \mu \mathrm{m}$. The silicates are coarser $(>100 \mu \mathrm{m})$ as they are harder minerals. The tailings contain c. $10 \%$ of grains $>100 \mu \mathrm{m}$ and $60-70 \%<20 \mu \mathrm{m}$. According to the operator, the tailings do not contain elevated levels of environmentally significant metals, as they are low in raw marble and are neither mined nor disposed. Process chemicals are expected to be associated with the solids (DNV GL, 2014).

Use of flocculation chemicals and mixing of tailings with seawater to increase slurry density increases the rate of settlement at the deposition location and minimises the dispersion of the tailings (Fig. 2). Most of the tailings are deposited close to the end of the pipeline. Only a small amount of particles spreads outside the area allocated for the STP ( $<6 \mathrm{~mm} /$ year; DNV GL, 2018). The water quality (turbidity, temperature and salinity) is measured continuously by a buoy with measuring equipment, moving up and down in the water column. Sediment quality and soft bottom communities are measured regularly. The water quality, including turbidity, has generally been good (<10 FTU (Formazin Turbidity Unit), with just short periods $>5$ FTU within the STP, and <5 FTU outside the STP (DNV GL, 2014, 2018).

Since 2007, discharges have been approximately 400-500 kilotons per year (DNV GL, 2014), reducing to approximately 200 kilotons in 2017 (DNV GL, 2018). There has been a massive reduction in tailings discharge because of higher quality raw materials, improvements in the production process, and measures taken by Omya Hustadmarmor to reuse tailings, e.g., for farming (used as agricultural lime) and deacidification of lakes and rivers. The amount of fresh water used has also decreased (DNV GL, 2014).

\section{Material and Methods}

Multibeam bathymetry data were collected with NGU's research vessel FF Seisma in 2015 and 2016, using a Kongsberg EM 2040 Dual RX multibeam echosounder. The echosounder was set to transmit signals 
(FM pulse, $200 \mathrm{kHz}$ ) in a fan of 130 degrees, and multibeam bathymetry and backscatter data were recorded. The data collected with FF Seisma were gridded at $1 \mathrm{~m}$. A Kongsberg Seapath 300+ was used for the positioning, and sound velocity profiles were recorded using a Valeport 650 sound velocity profiler with tidal corrections obtained from the Norwegian Mapping Authority (www.havnivå.no). The data were processed using Caris software.

Multibeam bathymetry data collected by Omya Hustadmarmor and DNV GL (Det Norske Veritas Germanischer Lloyd) in 2013, 2014 and 2017 were used to study changes in bathymetry over time. The datasets collected in 2013 and 2014 have lower resolution and contain more noise than the later datasets and were gridded at $2 \mathrm{~m}$, while the 2017 dataset was gridded at $1 \mathrm{~m}$. ArcGIS software was used to produce all the maps.

High-frequency seismic data (Fig. 3) were acquired using a Kongsberg TOPAS PS 40 parametric sub-bottom profiler. TOPAS uses a parametric acoustic source that forms a 5 degrees wide beam. The profiler was operated in chirp mode with primary frequencies of $36-39$ and $41-44 \mathrm{kHz}$, and chirp length of 10 milliseconds (ms). The returning signal was sampled within the frequency range $2-8 \mathrm{kHz}$ with a median frequency of $5 \mathrm{kHz}$. This sampling frequency gives a maximum vertical resolution $(\lambda / 4)$ of $7.5 \mathrm{~cm}$. However, it is not possible to distinguish features on the seismic data smaller than $(\lambda / 2) 15 \mathrm{~cm}$ (Lepland et al., 2009, Bøe et al., 2018). The seismic data were processed using TOPAS software (Kongsberg) and converted to jpeg2000 files using SegYjp2 software (Courtney, 2018). The data are visualised and interpreted using SegYjp2Viewer software (Courtney, 2018). An acoustic velocity of $1520 \mathrm{~m} / \mathrm{s}$ was used to estimate the thickness of tailings along the seismic profiles (Lepland et al., 2009).

Altogether, 20 grab samples, 8 Niemistö cores and 21 video transects were collected in August 2015 with FF Seisma (Tables $1 \&$ 2; Fig. 3). The Niemistö cores were logged at NGU using a multisensor core logger (MSCL) measuring wet bulk density (WBD) and magnetic susceptibility (MS), and the fractional porosity was derived from the wet bulk density. After lengthwise splitting and surface cleaning, core surface images were taken with the GeoScan IV colour line-scan camera. X-ray images (XRI) of split cores were taken with the Geotek MSCL-XCT (Geotek Ltd., UK) (see Knies et al., (2018) for a more detailed description of the

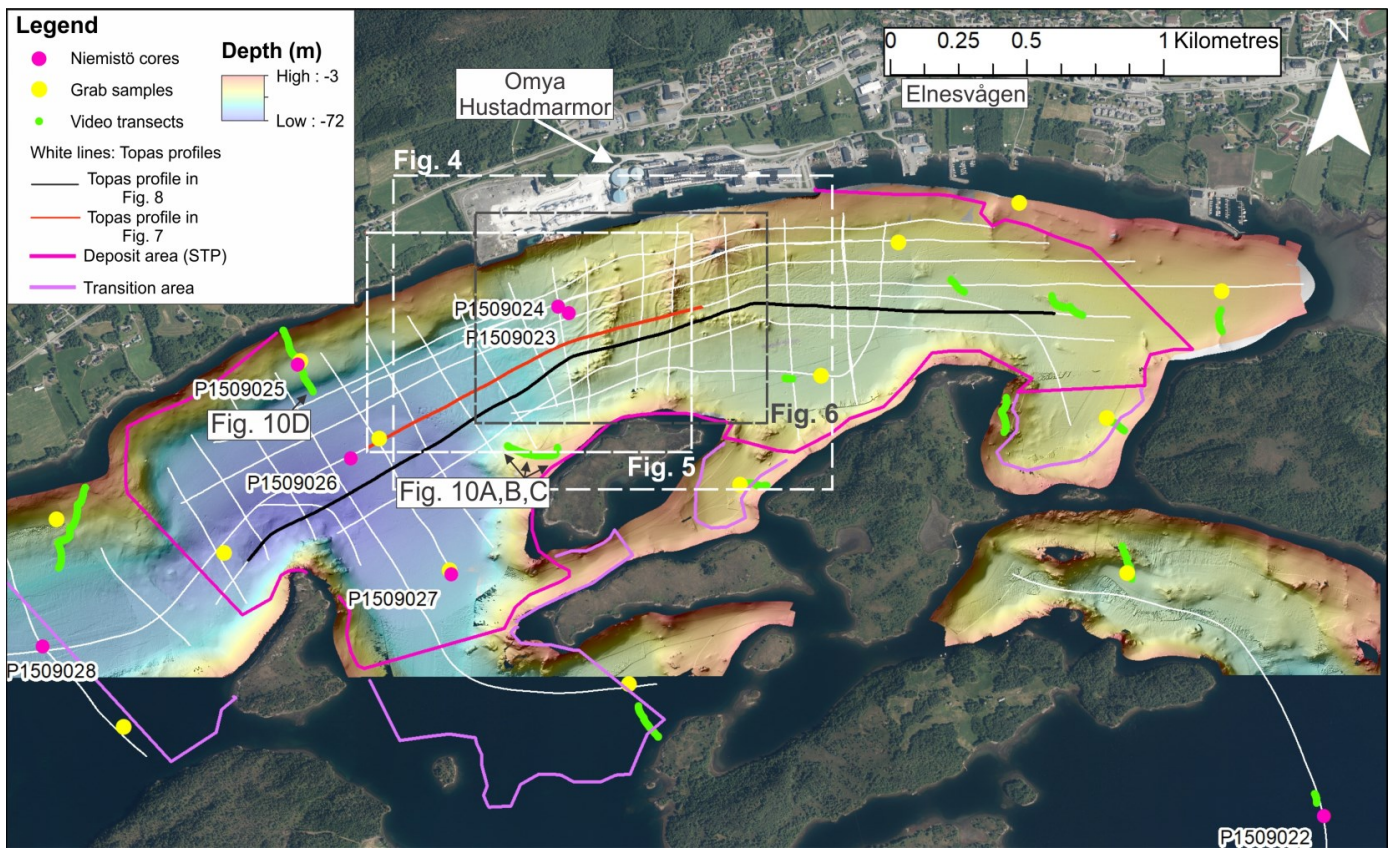

Figure 3. Multibeam bathymetry data collected by NGU in 2015 and 2016 with locations of TOPAS profiles, Niemistö cores, grab samples and video transects. The locations of Figs. 4, 5, 6 \& 10 are indicated. The deposit area (STP) and transition area are indicated with dark pink and light pink lines, respectively. 
Table 1. Cores collected by FF Seisma in Frænfjorden in August 2015.

\begin{tabular}{|c|c|c|c|c|c|c|}
\hline Core number & Equipment & $\begin{array}{l}\text { Water } \\
\text { depth } \\
(\mathrm{m})\end{array}$ & $\begin{array}{l}\text { Core } \\
\text { length } \\
\text { (cm) }\end{array}$ & $\begin{array}{l}\text { UTM } \\
\text { zone }\end{array}$ & Degrees $\mathrm{N}$ & Degrees $\mathrm{E}$ \\
\hline P1509021 & Niemistö corer & 63 & 29 & 32 & 62.814538 & 7.173444 \\
\hline P1509022 & Niemistö corer & 51 & 26 & 32 & 62.83003 & 7.168949 \\
\hline P1509023 & Niemistö corer & 39 & 60 & 32 & 62.845651 & 7.113796 \\
\hline P1509024 & Niemistö corer & 39 & 60 & 32 & 62.845865 & 7.112997 \\
\hline P1509025 & Niemistö corer & 38 & 30 & 32 & 62.84373 & 7.094453 \\
\hline P1509026 & Niemistö corer & 64 & 59 & 32 & 62.840731 & 7.098438 \\
\hline P1509027 & Niemistö corer & 54 & 27 & 32 & 62.837061 & 7.105902 \\
\hline P1509028 & Niemistö corer & 54 & 20 & 32 & 62.834322 & 7.07674 \\
\hline
\end{tabular}

methods). Analyses of total (TC) and organic carbon ( $\left.\mathrm{C}_{\text {org }}\right)$ were performed with a LECO SC-632. The grain-size distribution $(0.4 \mu \mathrm{m}-250 \mu \mathrm{m})$ was determined with a Coulter LS 200 . To compensate for erroneous recording of clay contents by the Coulter LS 200 instrument (compared to traditional methods such as pipette and Sedigraph), we applied the correction method published by Rise \& Brendryen (2013). The undisturbed and remolded shear strength of the sediments were measured using a fall cone test. The sensitivity is the ratio of undrained shear strength in undisturbed and remolded conditions.

Mineralogical analyses were carried out by XRD on unoriented preparations scanned by a Bruker D8 Advance diffractometer ( $\mathrm{Cu}$ Ka radiation in $3-75^{\circ} 2 q$ range). Mineral identification was carried out with an automatic and/or manual peak search and match function in Bruker's Diffraction EVA V3.1 software. Mineral quantification was performed using Rietveld modelling with software TOPAS 5 (see also Bøe et al., 2018).

\section{Results}

\section{Seabed morphology and changes over time}

The discharge of tailings takes place through an extendable pipeline that builds cone-shaped deposits on the seafloor. The pipeline is extended when the deposit reaches a minimum water depth of $30 \mathrm{~m}$, as stated in the permit for the activities under the Pollution Control Act granted by the Norwegian Environment Agency on 20 November 2015. In 2011, the practice changed from the use of a single pipeline ending to the use of both a single ending and a split ending to assure more stable deposits, giving it an octopus seafloor shape (Fig. 4). The cones have slope angles of $10-30^{\circ}$, decreasing to $5-9^{\circ}$ just outside the cones (Fig. 5). The fjord bottom further away from the discharge locations has slope angles typically below $3^{\circ}$ (Fig. 5) while the sides of the fjord may be steep and reach $40^{\circ}$, e.g., close to the processing plant (Fig. 5).

Multibeam bathymetry datasets acquired between 2013 and 2017 show changes in the STP over time (Fig. 6A-E). All three pipeline endings have been extended during this period, and a considerable amount of tailings has been deposited between 2013 and 2017, as shown in Fig. 6F. The deposits at the northern and eastern outlets have a thickness of up to $8 \mathrm{~m}$. At the southern outlet, the deposits reach a thickness of up to $10 \mathrm{~m}$ (Fig. 6F). 


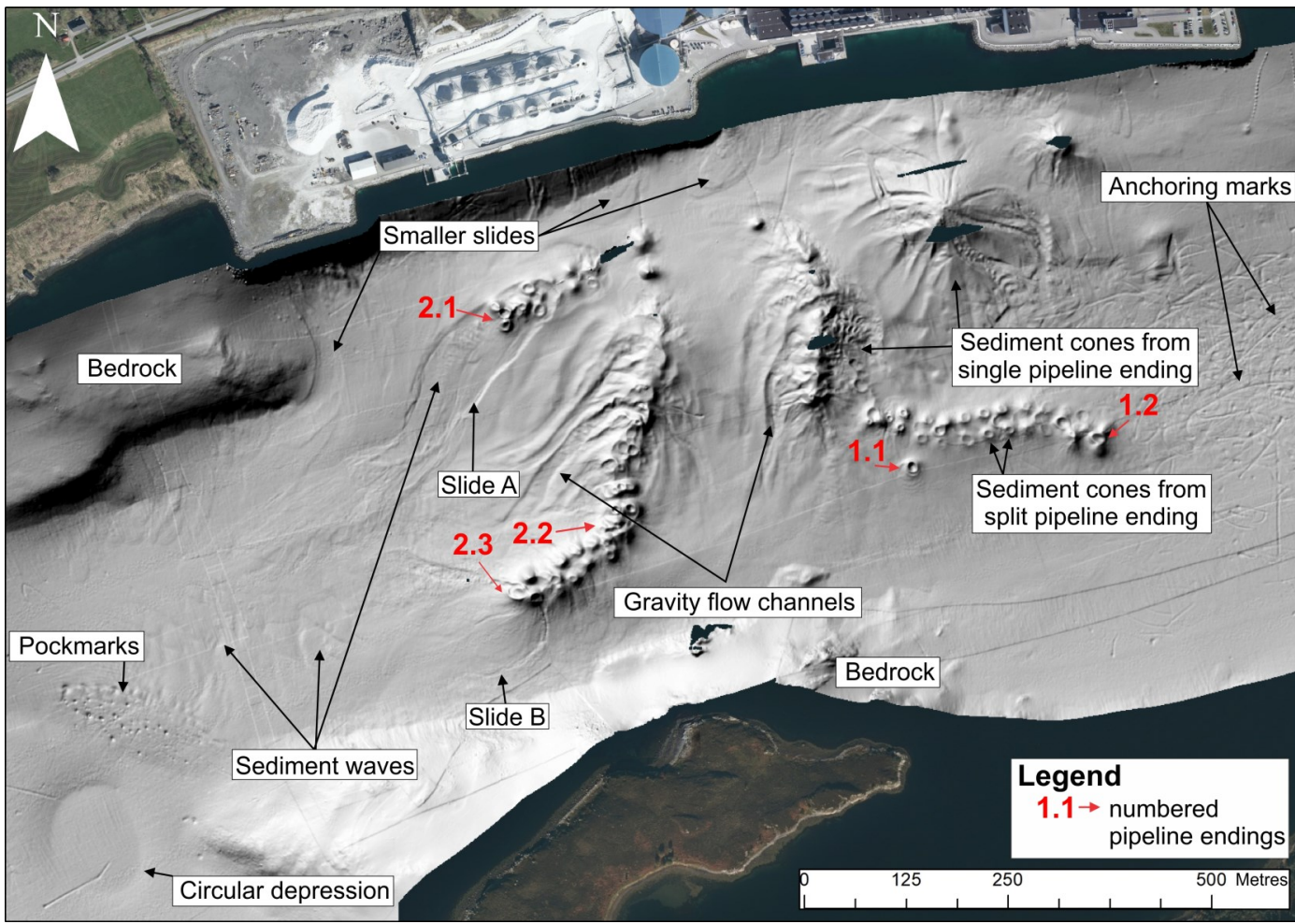

Figure 4. Shaded relief map (2016 multibeam bathymetry dataset) of the central part of the STP. The morphological interpretation and the different pipeline endings are indicated in the figure.

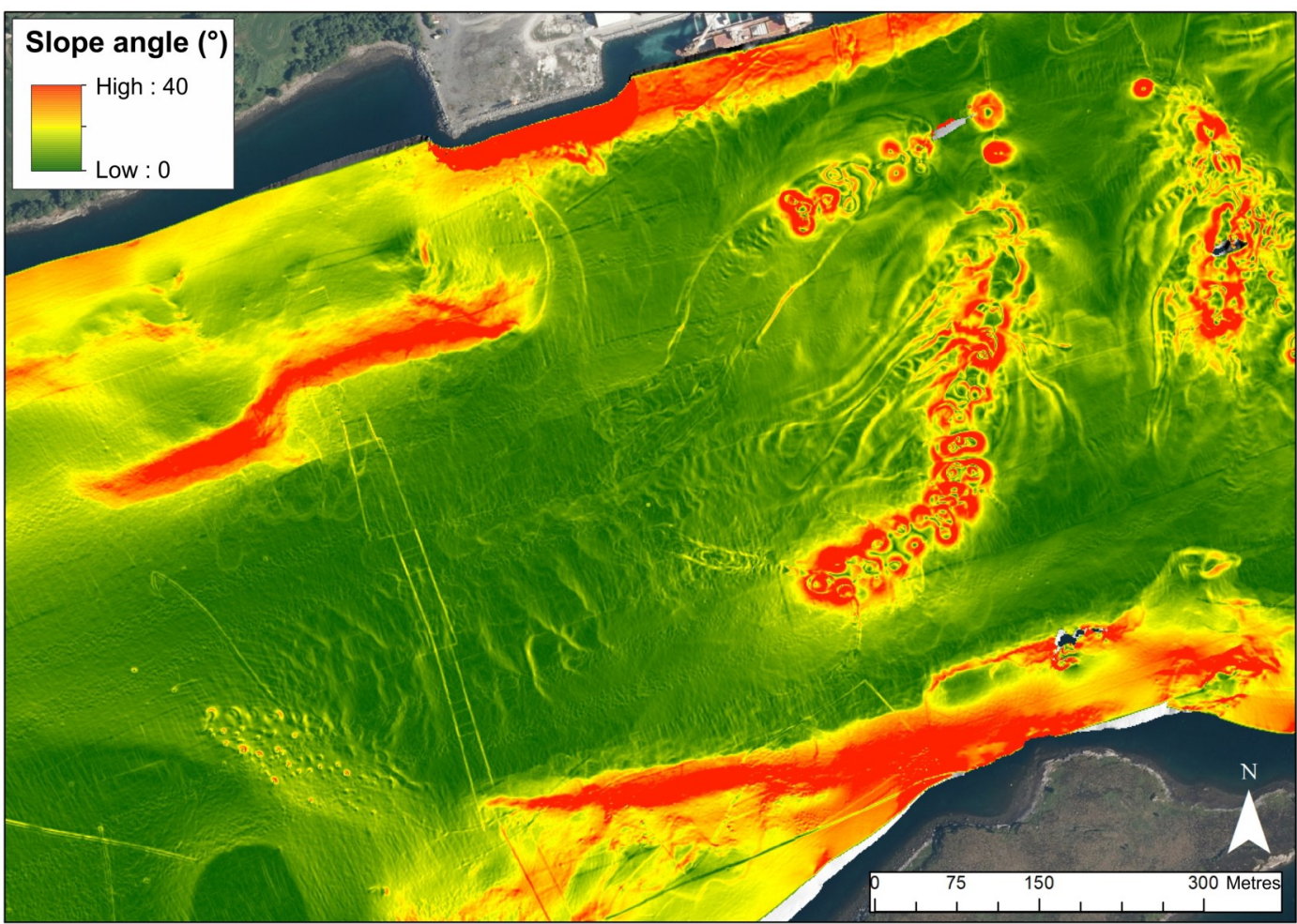

Figure 5. Slope map (2016 multibeam bathymetry dataset) of the central part of the STP, with the slope angle in degrees. 


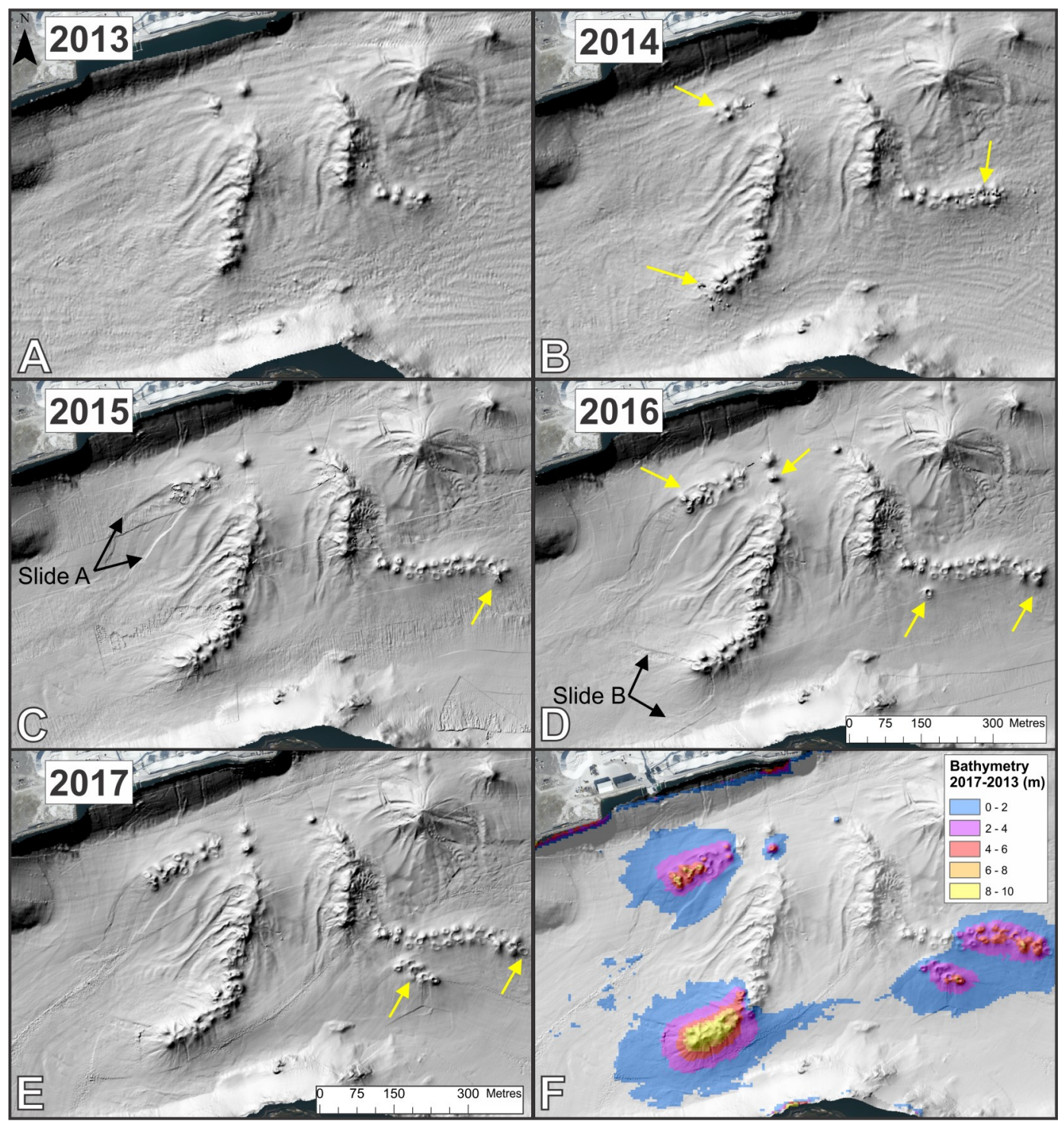

Figure 6. (A-E) Shaded relief of the central part of the STP in 2013 to 2017. Yellow arrows indicate changes in seafloor topography between the different years. Note slides A and B in 2015 and 2016. (F) Bathymetric difference between the 2013 and 2017 data visualised on the 2017 shaded relief bathymetry.

Gravity-flow channels originate from the cones formed at single pipeline endings (Figs. 4 \& 5). Two slides (Fig. 4) occur at the endings of pipelines 2.1 and 2.3 (Fig. 4). Slide A was triggered in the beginning of 2015 (Fig. 6C) possibly because of the placement of concrete weights on the seafloor that are connected to the floating pipeline to keep it in place (Fig. 2). The slide was noticed because the concrete weight and the pipeline moved downwards. A bathymetry survey conducted on the $5^{\text {th }}$ of February 2015 confirmed the presence of a slide. Slide A has a defined sediment lobe below the slide scar (Fig. 4). Slide B was triggered in the end of 2015 or the first half of 2016 (Fig. 6D). The slide scar is visible on the bathymetry data (Fig. 4).

Sediment waves occur within the gravity-flow channels and the slide scars. Downslope, the sediment waves spread out over a wider area as the gravity flows are no longer confined by gravity-flow channels (Figs. 4 \& 5). The sediment waves are also visible on the seismic data (Fig. 7). Smaller slides flow down from the fjord side outside the processing plant, with defined sediment lobes below the slide scars (Fig. 4). 
Pockmarks occur at the base of the slope, below the area with sediment waves (Fig. 4). The pockmarks are circular, 'fresh-looking' and 2-7 $\mathrm{m}$ in diameter. Two larger depressions are visible within the basin (Figs. 3 \& 4). The one in the east is circular and has a diameter of $135 \mathrm{~m}$ (Fig. 4). The depression in the west has a more oval shape and is $120 \mathrm{~m}$ across. Both depressions have flat bottoms. Numerous anchoring marks occur on the seabed in the eastern part of the STP (Fig. 4).

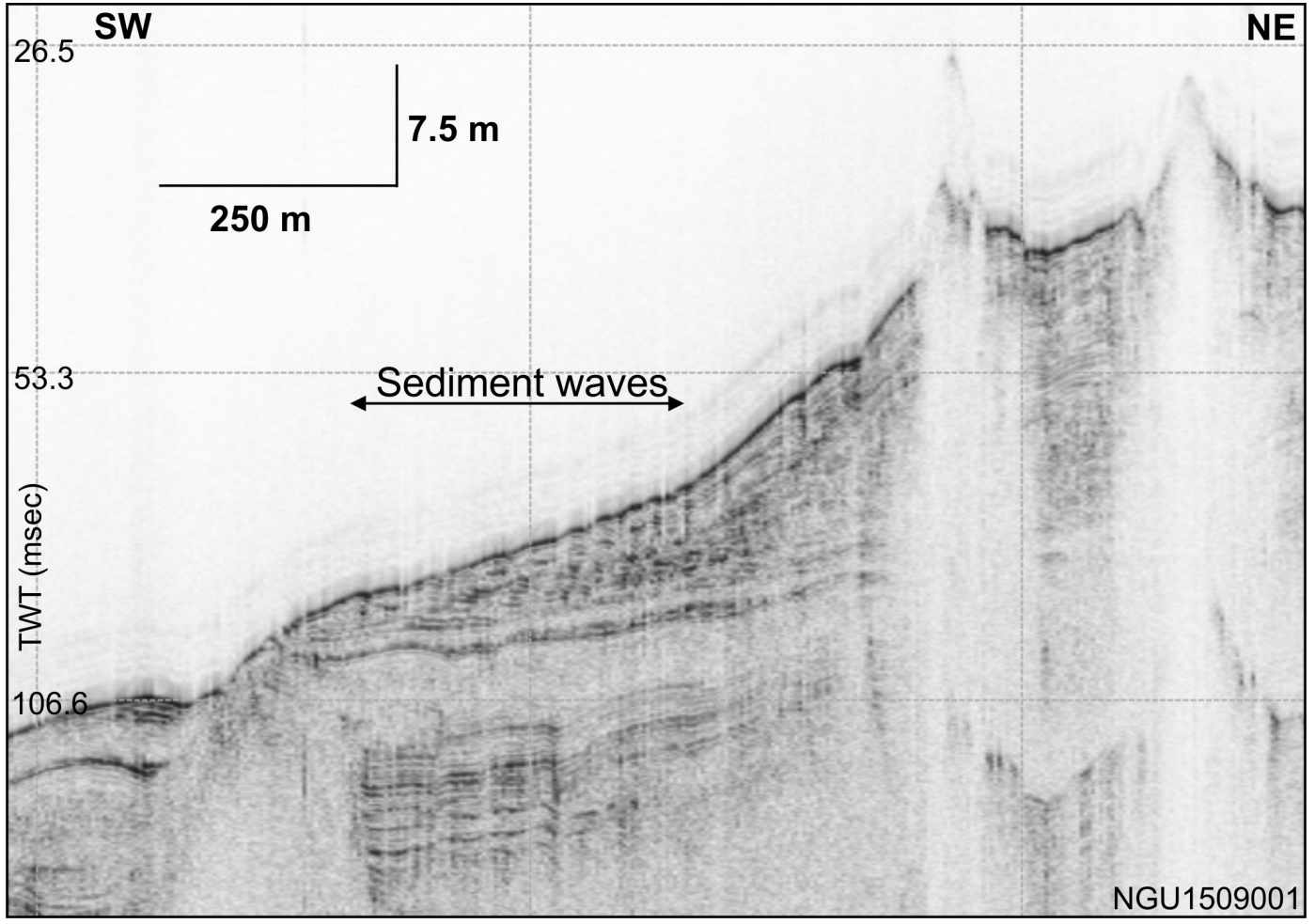

Figure 7. TOPAS profile showing sediment waves in the central part of the STP. See Fig. 3 for location.

\section{Seismic stratigraphy}

A seismic profile (Fig. 8) from the inner part of Frænfjorden shows four stratigraphic units. Unit 1 displays chaotic to laminar internal reflections and has a sharp and continuous lower boundary. It is present in the central part of the STP, where it is up to $2 \mathrm{~km}$ wide and $20 \mathrm{~m}$ thick. Unit 1 also occurs as an up to $40 \mathrm{~cm}$ thick layer in the basin west of the discharge location (Fig. 8).

Unit 2 can be traced throughout most of the inner fjord and has a transparent signature with a single, strong, continuous reflection approximately in the middle of the unit. It is up to $5 \mathrm{~m}$ thick and has a clear lower boundary in some areas and a more diffuse boundary in other areas. Unit 3 consists of laminated sediments draped over the undulating topography of Unit 4. This unit can be traced throughout the entire fjord, and has a variable thickness of up to $17 \mathrm{~m}$.

Unit 4 has a transparent signature and an undulating, diffuse upper boundary. It can be traced throughout the entire fjord, but its lower boundary is not visible on the seismic data. 


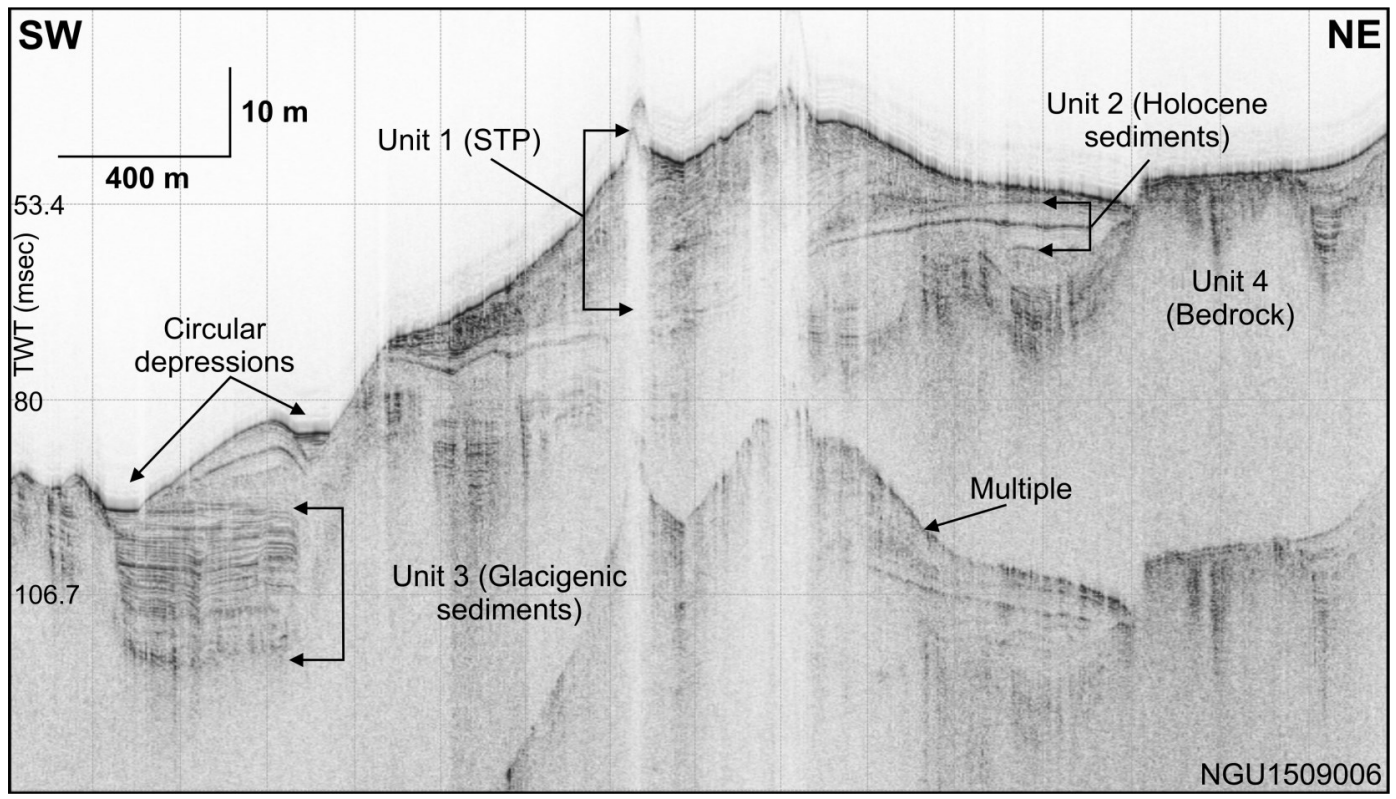

Figure 8. TOPAS profile along the inner part of Frænfjorden. See Fig. 3 for location.

\section{Seabed sediments (grain size)}

Multibeam backscatter intensities are very low around the pipeline endings used in 2016 (2.1, 2.3 and 1.2; DNV GL, 2017), the year in which the data were collected. These low backscatter intensities indicate finegrained sediments (Fig. 9). Further away from the pipeline endings, the seafloor is characterised by low to medium backscatter intensities, while the steep fjord sides show high backscatter intensities, indicating the presence of coarse-grained sediments.

Grab sample P1509009, collected close to the northern side of the fjord (Fig. 9), consists of olive-grey sandy mud changing gradually to a laminated light-grey mud on top (Fig. 9A, Table 2). Sample P1509010 was collected in the central part of the basin within the STP, west of the discharge location. It consists of very soft, laminated white/grey mud with a light-brown $2 \mathrm{~cm}$ cap (Fig. 9B). Sample P1509015 was collected southeast of the discharge location (Fig. 9). It consists of very soft, laminated white/grey mud (Fig. 9C). Sample P1509011, collected southwest of the discharge location, consists of dark olive-grey mud changing gradually to a $5 \mathrm{~cm}$ unit of light grey mud on top (Fig. 9D). Both P1509010 and P1509015 are poorly consolidated, and the sediments 'flow' out on deck as seen on the photographs (Fig. 9B, C). Grab samples P1509009 and P1509011 show a gradual change from dark olive-grey mud to light-grey mud and appear more consolidated than P1509010 and P1509015.

Four still images from the videos are shown in Fig. 10. Fig. 10A-C illustrates the change in sediment character along a transect from the southern fjord side towards the basin (see Fig. 3 for location). At the side of the fjord (Fig. 10A, water depth $20 \mathrm{~m}$ ), the sediments consist of sand, gravel and cobbles, and they are only partly covered by a thin layer of greyish-white sediments. Further down, the sediments consist of gravel, cobbles and boulders, and the cover of greyish-white sediments increases (Fig. 10B, $27 \mathrm{~m}$ water depth; Fig. 10C, $33 \mathrm{~m}$ water depth). Fig. 10D (water depth $55 \mathrm{~m}$ ) is from the basin, where the surface is completely covered by fine-grained, greyish-white sediments.

The grain-size map of Frænfjorden (Fig. 11) shows very fine, muddy sediments throughout the inner fjord, with coarser sediments at the sides of the fjord (a mixture of mud, sand, gravel, cobbles and boulders, and 
some areas with a thin or discontinuous sediment cover on bedrock). The discharge location is visible as an area of muddy sand at the pipeline outlets (Fig. 11). Sand-sized tailings deposit at the outlet of the pipeline while the fines travel further into the fjord.

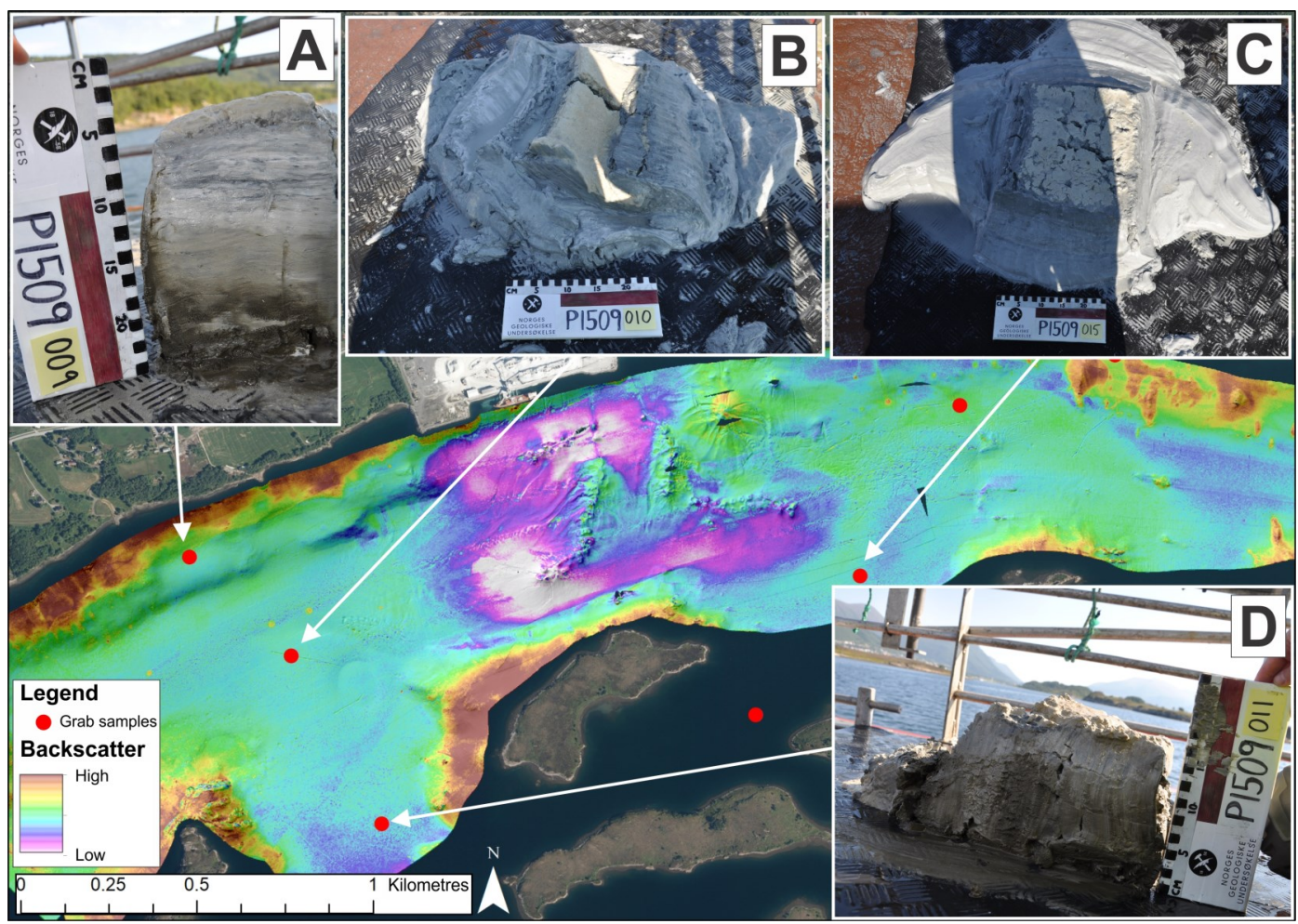

Figure 9. Multibeam backscatter intensity draped on shaded relief bathymetry from 2016. (A-D) Grab samples 1509009, 1509010, 1509015 and 1509011, respectively. See Table 2 for further details.

\section{Core descriptions}

Core P1509028 is situated outside the STP in the central part of the fjord, about $2.2 \mathrm{~km}$ southwest of the discharge location (Fig. 3; Table 1). It shows a gradual change from dark, olive-grey muddy sand at the bottom of the core to white/light-grey sandy mud at the top (Fig. 12). Bioturbation occurs between 5 and $12 \mathrm{~cm}$ depth while shell fragments occur in the middle and lower part of the core. Calcite content increases from $2 \%$ in the lower part of the core to $35 \%$ at the top (Table 3 ). The water content appears to be constant throughout the core. It was not possible to do a fallcone test on this core because of the high sand content.

Core P1509026 is situated within the STP in a basin about $850 \mathrm{~m}$ southwest of the discharge location (Fig. 3; Table 1). The lowermost lithological unit consists of dark, olive-grey massive to laminated sandy mud with a high content of silt, with greyish-white laminated mud with a high content of clay in the lithological unit on top (Fig. 13). A gradual transition between these two lithologies occurs between 37 and 39 $\mathrm{cm}$ depth. Calcite content increases from $3 \%$ at the bottom of the core to $90 \%$ in the upper part of the core (Table 3). The water content and the content of organic material are slightly higher in the sediments in the lower part of the core. Two fallcone tests show an increase in sensitivity towards the top of the core (from 2.5 to $5.2 \mathrm{kPa}$; Fig. 13). 
Table 2. Grab samples collected by FF Seisma in Frænfjorden in August 2015.

\begin{tabular}{|c|c|c|c|c|c|c|c|}
\hline $\begin{array}{l}\text { Grab } \\
\text { number }\end{array}$ & Equipment & $\begin{array}{l}\text { Water depth } \\
(\mathrm{m})\end{array}$ & Grain-size & Colour & Comments & Degrees N & Degrees $\mathrm{E}$ \\
\hline P1509001 & Grab & 70 & Muddy sand & Olive grey & Gravel $<3 \mathrm{~cm}$ & 62.831091 & 7.000175 \\
\hline P1509002 & Grab & 21 & $\begin{array}{l}\text { Sand, gravel and } \\
\text { cobbles }\end{array}$ & & $\begin{array}{l}\text { Empty grab } \\
\text { twice, large rock } \\
(3-10 \mathrm{~cm}) \text { in } \\
\text { opening }\end{array}$ & 62.836881 & 7.024842 \\
\hline P1509003 & Grab & 38 & $\begin{array}{l}\text { Sand, gravel and } \\
\text { cobbles }\end{array}$ & Olive grey & & 62.834231 & 7.027985 \\
\hline P1509004 & Grab & 26 & Muddy sand & Olive grey & & 62.82572 & 7.037645 \\
\hline P1509005 & Grab & 53 & Muddy sand & Olive grey & Light grey mud & 62.833575 & 7.055698 \\
\hline P1509006 & Grab & 40 & Muddy sand & $\begin{array}{l}\text { Light grey on top } \\
\text { of dark olive grey }\end{array}$ & $\begin{array}{l}\text { Top layer } 3 \mathrm{~cm} \\
\text { sandy mud on } \\
\text { top of muddy } \\
\text { sand }\end{array}$ & 62.831799 & 7.082678 \\
\hline P1509007 & Grab & 28 & $\begin{array}{l}\text { Gravelly muddy } \\
\text { sand }\end{array}$ & $\begin{array}{l}\text { Light greyish } \\
\text { brown }\end{array}$ & & 62.838471 & 7.077451 \\
\hline P1509008 & Grab & 64 & $\begin{array}{l}\text { Gravelly sandy } \\
\text { mud }\end{array}$ & $\begin{array}{l}\text { Light greyish } \\
\text { white on top of } \\
\text { olive grey }\end{array}$ & $\begin{array}{l}\text { Top layer mud } 7 \\
\mathrm{~cm} \text { on top of } \\
\text { muddy sand with } \\
\text { cobbles }\end{array}$ & 62.837549 & 7.08953 \\
\hline P1509009 & Grab & 39 & Sandy mud & $\begin{array}{l}\text { Light greyish } \\
\text { white on top of } \\
\text { olive grey }\end{array}$ & $\begin{array}{l}\text { Top layer mud } 15 \\
\mathrm{~cm} \text { on top of } \\
\text { sandy mud }\end{array}$ & 62.843839 & 7.094583 \\
\hline P1509010 & Grab & 64 & Mud & Light grey & $\begin{array}{l}\text { Light brown top } \\
\text { layer }(2 \mathrm{~cm})\end{array}$ & 62.841413 & 7.100417 \\
\hline P1509011 & Grab & 58 & Mud & $\begin{array}{l}\text { Light greyish } \\
\text { white on top of } \\
\text { olive grey }\end{array}$ & Top layer $5 \mathrm{~cm}$ & 62.837202 & 7.105736 \\
\hline P1509012 & Grab & 39 & Mud & Olive grey & $\begin{array}{l}\text { Top layer of } 1 \mathrm{~cm} \\
\text { with light grey } \\
\text { brownish mud }\end{array}$ & 62.833669 & 7.118825 \\
\hline P1509013 & Grab & 16 & Muddy sand & Dark olive grey & & 62.827469 & 7.10701 \\
\hline P1509014 & Grab & 24 & $\begin{array}{l}\text { Gravelly muddy } \\
\text { sand }\end{array}$ & $\begin{array}{l}\text { Light grey on top } \\
\text { of dark brown }\end{array}$ & $\begin{array}{l}\text { Top layer with } 5 \\
\mathrm{~cm} \text { sandy mud on } \\
\text { top of muddy } \\
\text { sand }\end{array}$ & 62.840261 & 7.126378 \\
\hline P1509015 & Grab & 41 & Mud & $\begin{array}{l}\text { Light greyish } \\
\text { white }\end{array}$ & & 62.843864 & 7.131963 \\
\hline P1509016 & Grab & 33 & Mud & Light grey & $\begin{array}{l}\text { Light brown top } \\
\text { layer }\end{array}$ & 62.848279 & 7.137243 \\
\hline P1509017 & Grab & 17 & Muddy sand & Dark olive grey & & 62.849676 & 7.145819 \\
\hline P1509018 & Grab & 22 & Sandy mud & $\begin{array}{l}\text { Dark grey/dark } \\
\text { greyish brown }\end{array}$ & $\begin{array}{l}\text { With a light grey } \\
\text { brownish top } \\
\text { layer }\end{array}$ & 62.846997 & 7.160545 \\
\hline P1509019 & Grab & 28 & Muddy sand & $\begin{array}{l}\text { Light grey on top } \\
\text { of dark brown }\end{array}$ & Top layer $3 \mathrm{~cm}$ & 62.842771 & 7.15256 \\
\hline P1509020 & Grab & 39 & Mud & $\begin{array}{l}\text { Dark greyish } \\
\text { brown }\end{array}$ & Brown top layer & 62.837757 & 7.154308 \\
\hline
\end{tabular}




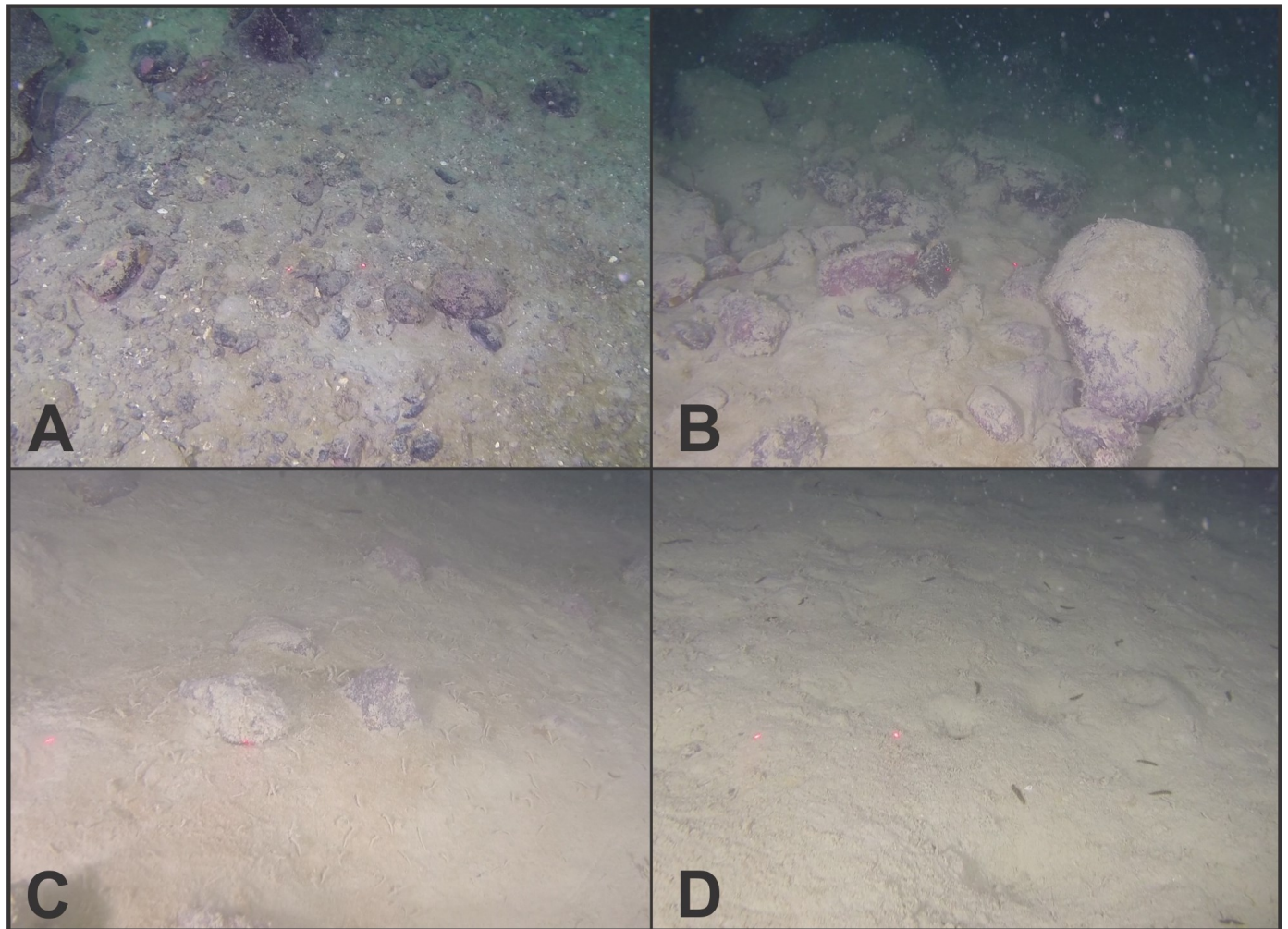

Figure 10. Still images of the seabed from video transects. Horizontal scale: $10 \mathrm{~cm}$ between the red laser dots. See Fig. 3 for location.

Core P150924 is situated in the STP within Slide A (Figs. 3 \& 4; Table 2). It consists of greyish-white, laminated mud at the bottom of the core and grey, laminated sandy mud at the top (Fig. 14). A sharp, inclined boundary between the two lithologies occurs at $25-28 \mathrm{~cm}$ depth. The calcite content decreases slightly from $90 \%$ at the bottom of the core to $82 \%$ at the top of the core (Table 3 ). Water content and sensitivity are stable throughout the core. The content of organic material is slightly higher at the top of the core.

Core P1509022 is situated outside the STP in the northern part of the Malmefjorden basin (Figs. 1 \& 3; Table 1), about $3 \mathrm{~km}$ southeast of the discharge location. It consists of sandy mud with a very high content of silt (Fig. 15). The colour changes from black at the bottom of the core to brown at the top. The content of organic material is $7-10 \%$, and the water content is very high (300\% compared to $50-75 \%$ in the other sediment cores). The calcite content increases from $2 \%$ to $27 \%$ towards the top of the core (Table 3 ), and the sensitivity is relatively low (1.5 kPa; Fig. 15).

\section{Discussion}

In this chapter we discuss the character of the tailings and the natural sediments, the distribution of the tailings in the fjord, the processes behind their spreading, and the redeposition by mass movements. 


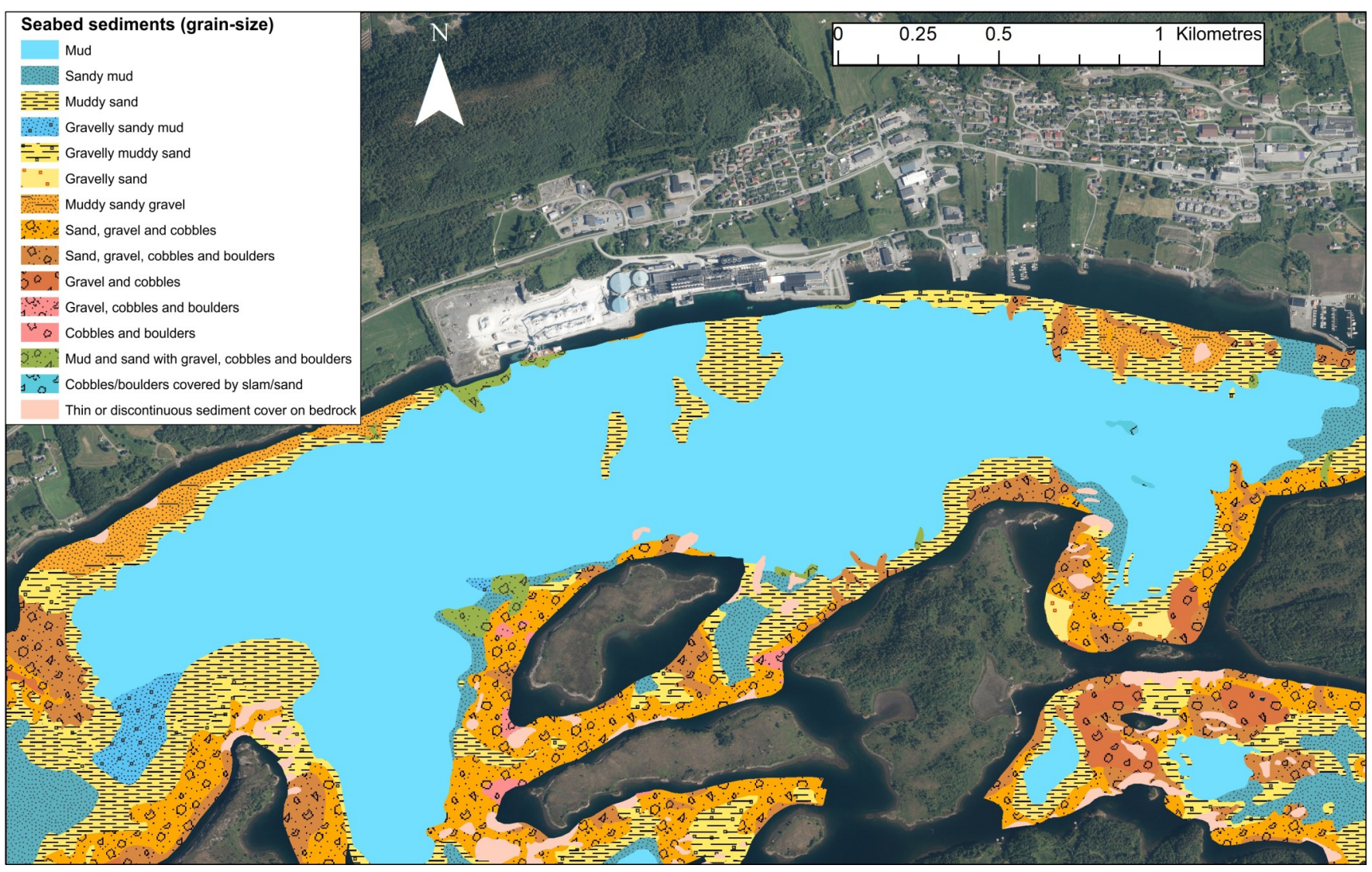

Figure 11. Seabed sediments (grain size) of the investigated area.
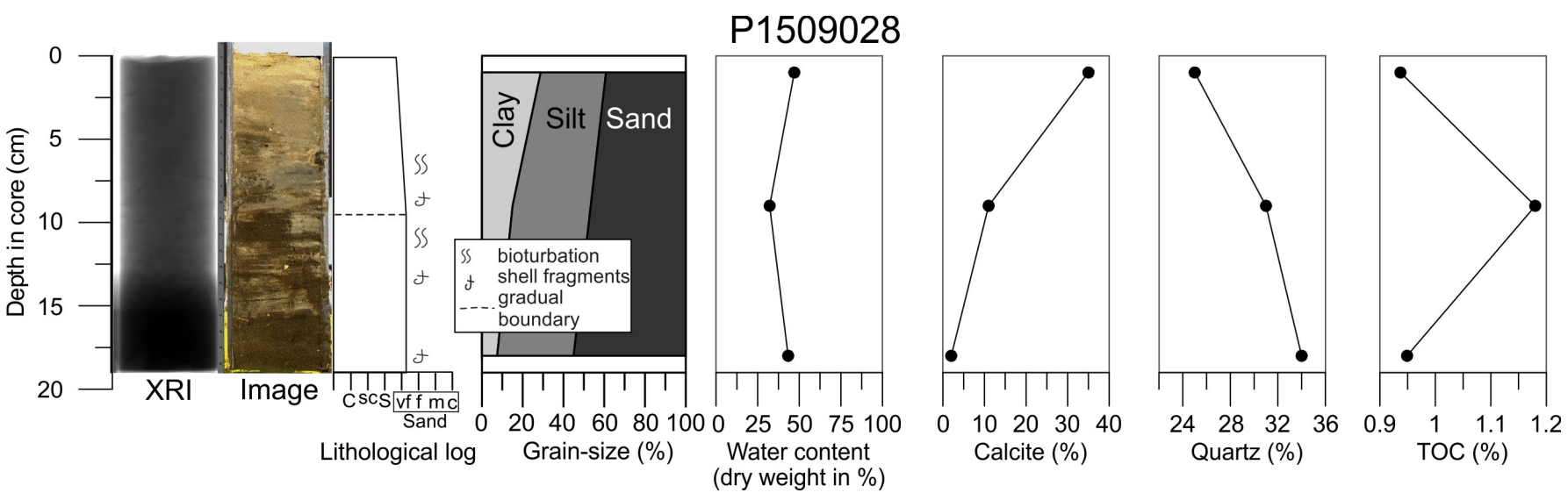

Figure 12. Lithostratigraphy, physical properties and mineralogy of core P1509028. See Fig. 3 for location.

\section{Composition and distribution of tailings}

The sediment grain-size map in Fig. 11 shows that fine-grained sediments (mud) dominate the seafloor within the STP in the inner part of Frænfjorden. The tailings being disposed in Frænfjorden contain 50$60 \%$ calcium carbonate (DNV GL, 2018). However, sediments collected some distance away from the 


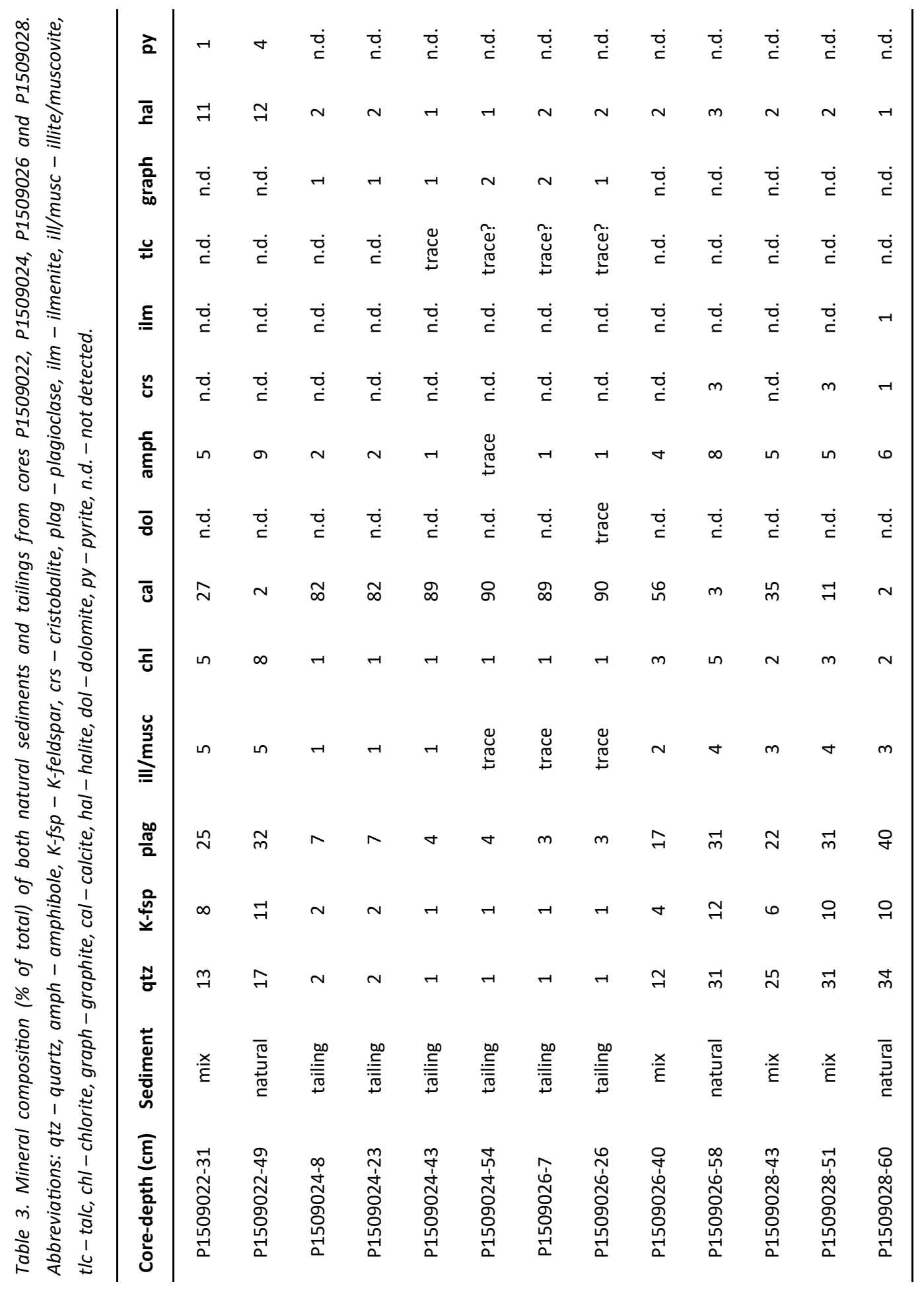



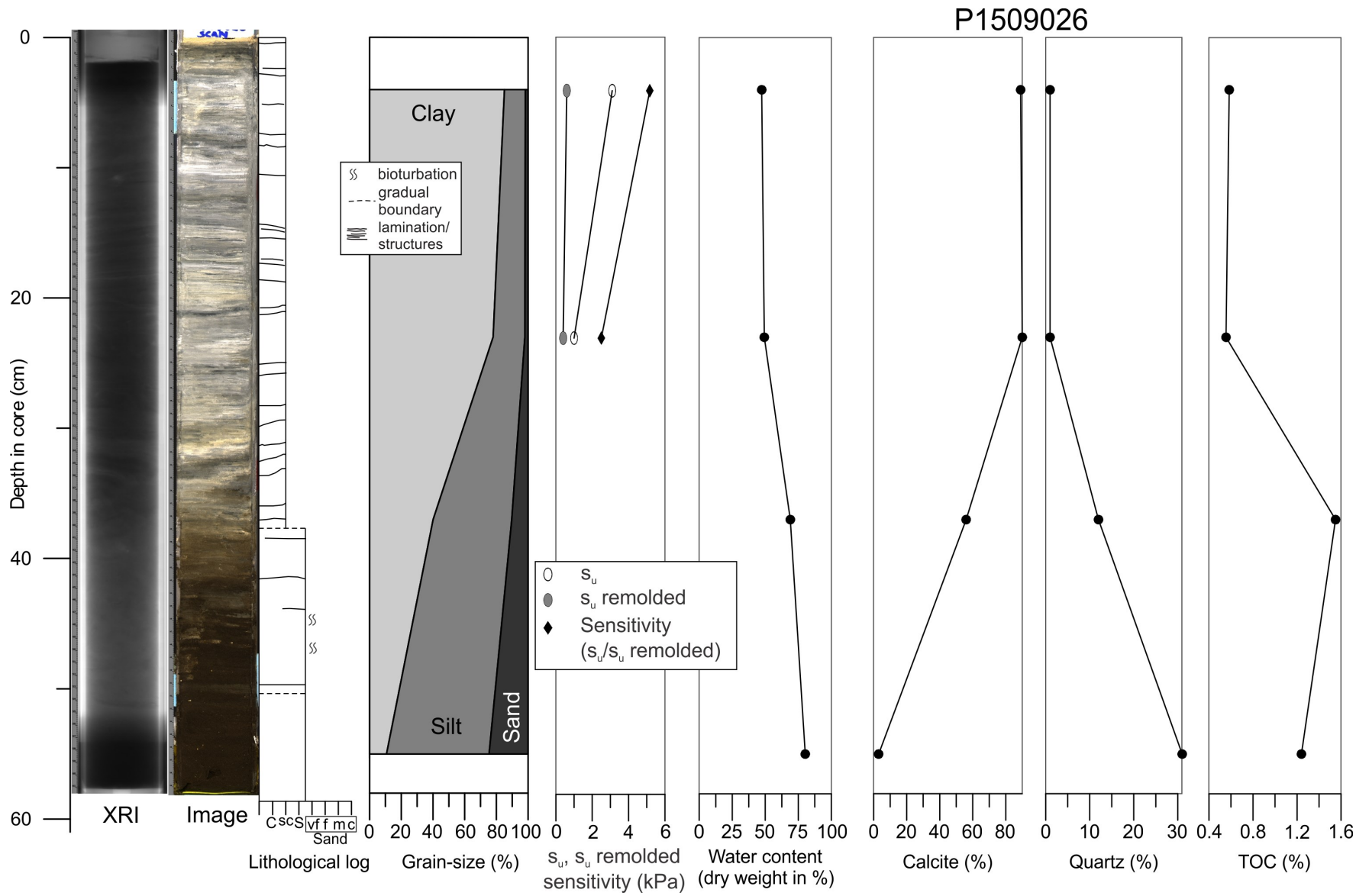

Figure 13. Lithostratigraphy, physical properties and mineralogy of core P1509026. See Fig. 3 for location.
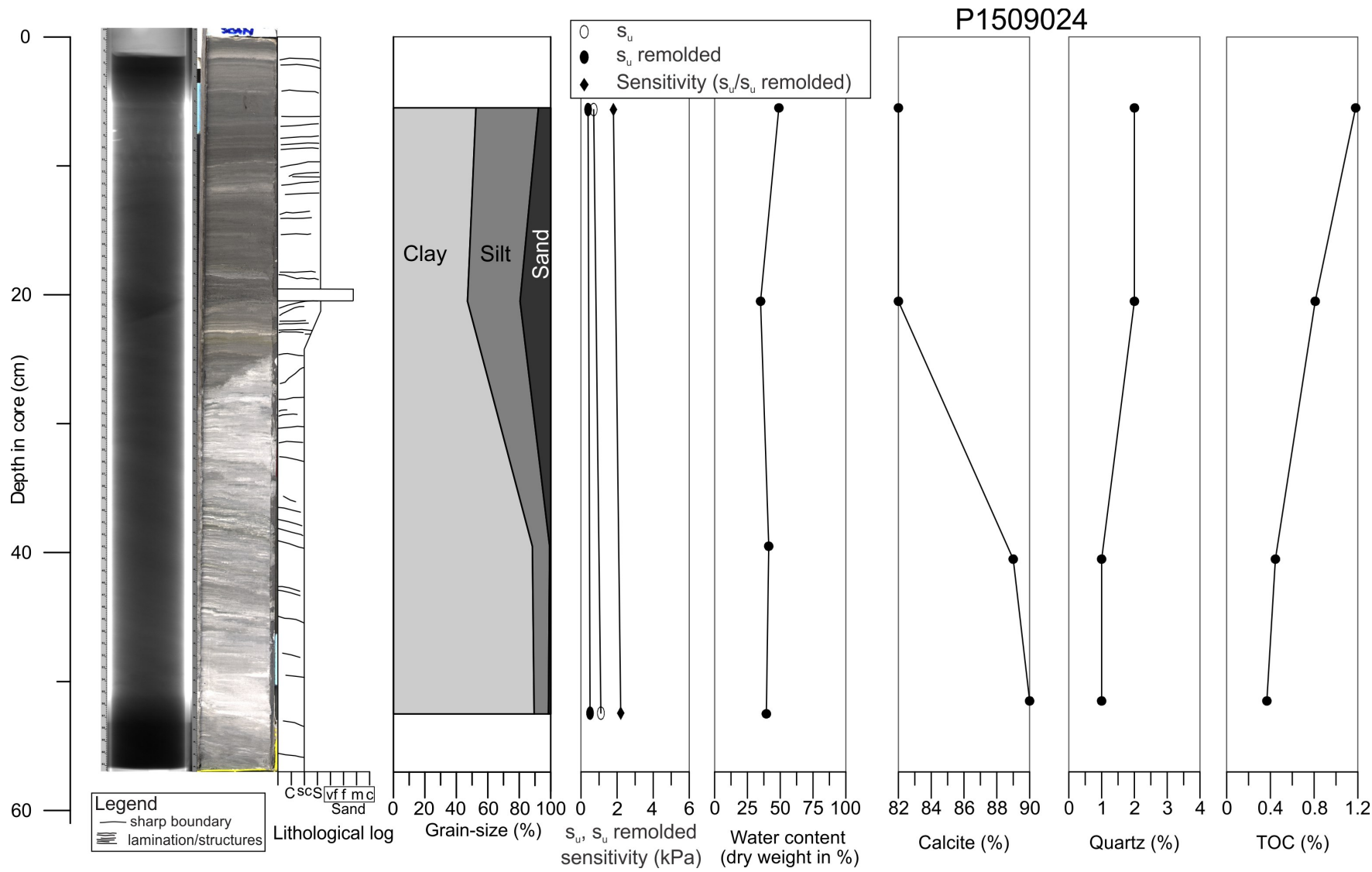

Figure 14. Lithostratigraphy, physical properties and mineralogy of core P1509024. See Fig. 3 for location. 


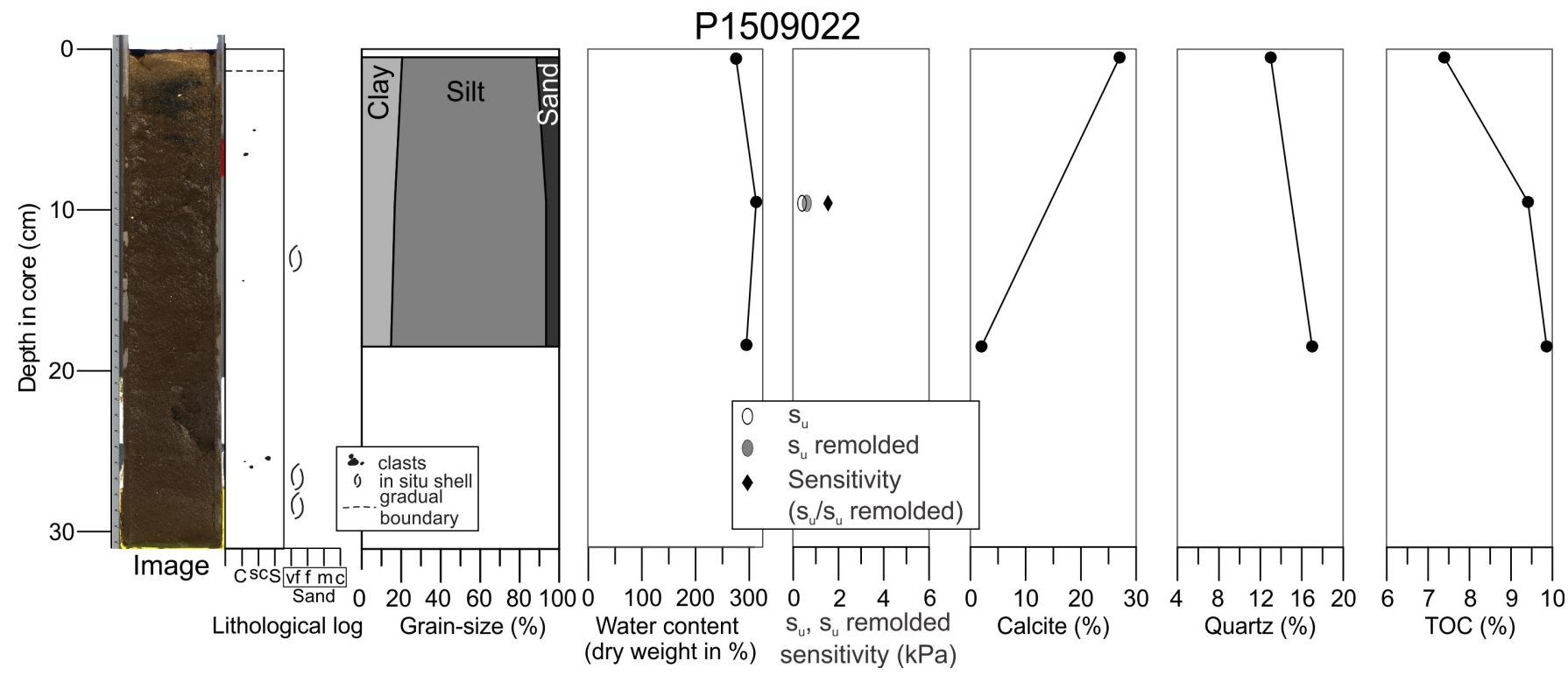

Figure 15. Lithostratigraphy, physical properties and mineralogy of core P1509022. See Fig. 3 for location.

pipeline ending typically contain $80-90 \%$ calcite because calcite mainly occurs as fine fractions below 20 $\mu \mathrm{m}$, which move away from the pipeline in suspension. The coarser silicate particles (mainly above 100 $\mu \mathrm{m})$ are deposited directly at the ending of the pipeline.

The tailings have a greyish-white colour (Fig. 2), distinctly different from the dark-grey natural sediments that contain just a few percent calcite. Tailings are therefore easily recognisable in videos and core/grab samples (Figs. 9, 13 \& 14). Core P1509026 (Fig. 13), from the basin west of the discharge location (Fig. 3), intersects the transition from natural sediments to tailings and provides a representative example of change in colour (from dark-grey to greyish-white), grain size (from sandy silt to clay) and calcite abundance (from 3 to 90\%).

In the central part of Frænfjorden, about $2.2 \mathrm{~km}$ southwest of the discharge location (core P1509028), calcite content increases from a natural level of $2 \%$ to $35 \%$ at the core top, indicating that most recent sediments represent a mixture of tailings and natural sediments. In Malmefjorden, southeast of the STP, calcite content increases from $2 \%$ to $27 \%$ towards the top in core P1509022. This indicates mixing of natural sediments with increasing amounts of tailings towards the top of the core, albeit less than in core P1509028. The natural silt-dominated sediments in Malmefjorden are very rich in organic material with a TOC content of $7-10 \%$ and a very high water content (dry weight of $300 \%$ compared to $50-75 \%$ in the other sediment cores).

Right next to the discharge location, core P1509024 consists of tailings with a calcite content of $82-90 \%$ (Fig. 14). A sharp, inclined boundary between 25 and $28 \mathrm{~cm}$ depth separates two units with a distinct colour difference. The dark-grey upper unit is coarser grained (siltier-sandier), has a higher TOC content (Table 3 ) and contains slightly higher amounts of silicate minerals compared to the lower unit. This colour and compositional contrast between two units in core P1509024 is likely caused by compositional heterogeneity of the raw material. As this core is situated within a slide scar (Figs. 3 \& 4), the sharp inclined boundary could be the base of a smaller (translational) slide.

The lateral extent of tailings and their thickness can also be estimated using data from seismic profiling. Unit 1 on the seismic data has been interpreted to represent the tailings, based on its chaotic seismic 
signature and its occurrence in the central part of the STP (Fig. 8). This unit is up to $2 \mathrm{~km}$ wide and $20 \mathrm{~m}$ thick at the discharge location. An up to $40 \mathrm{~cm}$-thick unit was found within the sediment accumulation basin west of the discharge location (Fig. 8 \& 13). Unit 1 was not found anywhere else, indicating that the thickness of tailings elsewhere is less than the resolution of the seismic data of approximately $15 \mathrm{~cm}$. The lateral extent of Unit 1 (excluding the thin deposit found in the basin west of the discharge location) allows contouring of the edges of the STP visible on the seismic data (Fig. 16A).

Seismic Unit 2 (Fig. 8), immediately below Unit 1, has been interpreted to consist of homogeneous, finegrained sediments deposited from suspension during the Holocene. The strong reflection in the middle of the unit could be interpreted as a turbidite or a debris-flow deposit. Two prominent reflections in Julsundet (about $11 \mathrm{~km}$ south of the mouth of Frænfjorden; Fig. 1) are interpreted to represent local climate-triggered sedimentation irregularities with a minimum age of $3222 \mathrm{cal}$. BP, and a turbidite with a maximum age of 9447 cal. BP related to the Storegga Slide tsunami ( 8200 cal. BP) (Bøe et al., 2004a). It is possible that the prominent reflection within Unit 2 in Frænfjorden can be correlated to one of these two events.

Unit 3 is interpreted to consist of glacimarine sediments because it occurs draped on the undulating topography of Unit 4 and because of its laminated seismic signature (see also Bøe, 1987). Similar glacimarine units with laminated seismic signatures occur in most Norwegian fjords (e.g., Bøe et al., 2003, 2018, Rise et al., 2006, Hjelstuen et al., 2013, Bellwald et al., 2016, Hansen et al., 2018). This unit can be

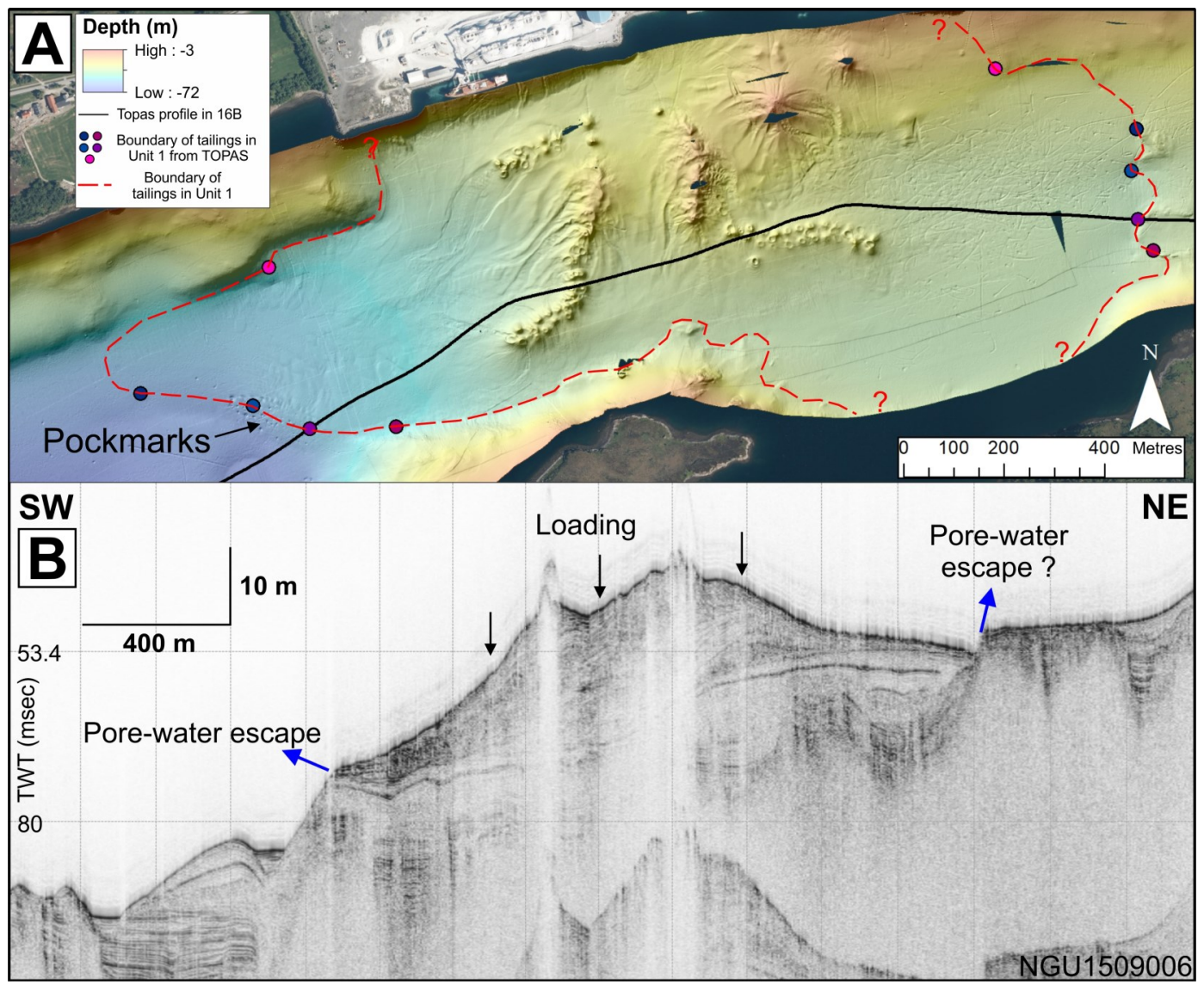

Figure 16. (A) Outer boundary of tailings in Unit 1 (red stippled line) interpreted from TOPAS profiles plotted on multibeam bathymetry from 2016. Note the location of pockmarks along the western boundary. (B) TOPAS profile showing interpreted locations of pore-water escape forming pockmarks along the boundary of the tailings in Unit 1 due to overpressure. 
traced throughout the fjord and changes in thickness (up to $17 \mathrm{~m}$ ). Because of its undulating topography, Unit 4 is interpreted to comprise bedrock, probably with a local drape of till (Fig. 8). The till, however, cannot be discerned in the TOPAS data due to lack of penetration.

Comparison of bathymetric datasets demonstrates that between 2013 and 2017, an up to 8-10 m thick package of tailings has been deposited within the STP (Fig. 6F) giving a maximum tailings accumulation rate of 2-2.5 m/year, and an average rate of 1-1.25 m/year during this time period. This correlates well with findings by Hustadmarmor/DNV GL of a depth reduction of up to $10 \mathrm{~m}$ since 2014 close to the outlet pipes (DNV GL, 2018).

Considering that the thickness of tailings visible on the seismic data varies between c. 0.4 (in the basin) and $20 \mathrm{~m}$ (at the discharge location; Fig. 8) and discharge started in 1982, the average accumulation rate of the tailings is c. $30 \mathrm{~cm} /$ year over a period of 34 years. The difference between these calculations could be attributed to increased discharge in more recent years. The thickness of tailings can also be influenced by compaction and consolidation of the older tailing deposits. The factory as it is today was established in the 1990s, and the disposal of tailings increased from $<100,000$ tons/year to almost 500,000 tons/year in 1999-2000. The disposal was on average about 350,000 tons/year in the following 10 years, and was reduced to 200,000-250,000 tons/year during the most recent years (personal communication with OMYA Hustadmarmor).

Bathymetric (Fig. 6F), seismic (Fig. 8), and sediment core (Figs. 12, 13, 14 \& 15) data show that the majority of the tailings are deposited in the immediate vicinity of the discharge location with minor quantities being spread outside the STP (Core P1509022 and P1509028; Figs. 12 \& 15). Findings by DNV GL (2016) confirm that tailings are spread outside the boundary of the STP, but historical data show that the area with tailings does not expand. The estimated deposition of tailings at the STP boundary was $6 \mathrm{~mm} / \mathrm{year}$ ( $30 \mathrm{~mm} / 5$ years), which is within the acceptance criteria (DNV GL, 2016).

Two circular depressions in the seafloor occur in the west side of the STP (Figs. 3, 4 \& 8). A current model from SINTEF (Nepstad et al., submitted) shows the presence of eddies close to the depressions and thus infers a close relationship between the two. The eddies might have caused erosion of the depressions and/ or prevented deposition of sediments within. At present, however, they appears to be filled in. The depressions might have originated as pockmarks related to vertical fluid flow in the past, possibly before the start of the Holocene.

Tailings found outside the STP have been transported in a suspension plume, spread by winds, currents and waves (Nepstad et al., submitted). The spreading of particles in suspension depends on several factors such as particle size, settling velocity and water column stratification. The dispersion of a sediment plume will be greater during periods of stronger stratification (Taylor, 1953; Ramirez-Lodra et al., 2015). There are several measures that can minimise the dispersion of tailings; thickening and de-aeration of tailings and particle flocculation (see Fig. 2). Prior to de-aeration, the tailings are usually thickened to recycle water and process chemicals (Skei, 2014).

\section{Redistribution of tailings by mass movements}

Slope failures in and around STPs are important because they may result in re-suspension and dispersal of tailings to areas outside the STP (Burd et al., 2000; Ramirez-Lodra et al., 2015). Slope failures are generally not considered in risk assessments for STP/DSTPs and are often poorly documented (Burd et al., 2000). It is therefore important to understand the processes leading to slope failures in STPs. 
In Frænfjorden, two slides and several gravity-flow channels originate from the deposited cones at the discharge locations (Fig. 4). The multibeam bathymetry data shows that the slides were triggered in 2015 and 2016 (Fig. 6).

Most of the gravity-flow channels contain sediment waves, indicating periodically strong bottom currents with sediments transported down the channel by density/turbidity currents. Similar active sediment waves, gravity-flow processes and slides are observed from tailings disposal in, for example, Stjernsundet (northern Norway). In Stjernsundet, these gravity-flow processes and slides transport mine tailings from their discharge location at the shoreline in the bay of Lillebukt, to deeper waters (Bøe et al., 2018).

The sediment waves continue down the slope, below the gravity flow channels (Fig. 4 \& 5) where they occur over a wider area not confined to channels (Fig. 5). On the seismic data (Fig. 7), the waves seem to migrate upslope, towards the east. Similar seismic signatures have been observed on the seafloor in Trondheimsfjorden, where turbidity currents and density currents overflow the margins of the Gaulosen Channel to create sediment waves that migrate upslope (Bøe et al., 2004b). The sediment waves in the lower part of the slope in Frænfjorden resemble creep folds caused by slow, downslope mass movement under gravitational stress (Fig. 7; e.g., Syvitski et al., 1987; Lee \& Chough, 2001; Bøe et al., 2004b; Shillington et al., 2012), and may be influenced by such a process. The sediment waves are clearest on the seismic data in the upper part of Unit 1 (Fig. 7) and are therefore most likely relatively young.

Most of the gravity-flow channels originate from cones deposited by single pipeline endings (not split pipeline endings) (Fig. 4), suggesting that tailings discharge from split pipelines gives more stable deposits on the STP.

Several preconditioning factors and triggering mechanisms lead to slope failures within the STP. Sediment accumulation rates are high, preventing normal consolidation of the sediments (Sultan et al., 2004). High sediment accumulation rates (anthropogenically-induced hyper sedimentation) produce thick packages of unconsolidated fine sediments that are susceptible to natural disturbances, which may again cause largescale slope failure (Burd et al., 2000). The grab samples in Fig. 9 illustrate the difference in consolidation between tailings close to a discharge location with loose and unconsolidated sediments (Fig. 9B, C), and semi-consolidated tailings mixed with natural sediments farther away from the discharge location (Fig. $9 \mathrm{~A}, \mathrm{D})$. The tailings have a finer grain size, and a higher sensitivity $(2.2-5.2 \mathrm{kPa})$ than the natural sediments, (1.5 kPa; Fig. 13, 14 \& 15), making them more susceptible to failing.

The natural sediments in Frænfjorden, especially in the inner part of the fjord, have a high water content (Fig. 15). The water content within the natural sediments is slightly higher than within the tailings, also in the basin west of the discharge locations (Fig. 13). The loading of up to $20 \mathrm{~m}$ of tailings on top of these natural sediments can cause overpressure, and possibly lead to pore-water flow at the interface between natural sediments and tailings, and expulsion to the seafloor at the outer boundary of Unit 1 (defined from seismic data). The occurrence of a chain of pockmarks along the boundary (Fig. 16A, B) is an indication of such loading triggered pore-water expulsion. Excess pore pressure generated by high sedimentation rates during peak glaciation has been suggested to precondition large submarine landslides on the Norwegian continental margin (e.g., Bryn et al., 2005, Kvalstad et al., 2005, Leynaud et al., 2009).

Deposition of tailings beside the discharge pipe leads to build-up of cones, creating higher slope angles. Slope angle is a key parameter for slope-stability assessment because it drives the destabilizing loading forces through gravity (Wilhelm et al., 2016). Slope stability typically decreases with increasing slope angle (Ai et al., 2014). Fig. 5 shows that the slope angles of the cones created by the discharge of tailings, and at the sides of the fjord $\left(5-40^{\circ}\right)$ are higher than the slope angles in the rest of the fjord $\left(<4^{\circ}\right)$. Slides and gravity flows are triggered by increasing slope angle/oversteepening related to continuous deposition on the STP cones. 
Slide A, in 2015 (Fig. 6C), was most likely triggered by the placement of a concrete weight on the seafloor to extend the floating pipeline. These concrete weights add extra pressure on the already unstable seafloor and can thus trigger slides.

\section{Conclusions}

The main findings of this study are:

1. The tailings are primarily deposited within the STP within an up to $2 \mathrm{~km}$-wide area with a tailing thickness of up to $20 \mathrm{~m}$. Minor quantities are spread outside of the STP by tidal currents.

2. The tailings have a white/grey colour, consist of very fine-grained sediments, contain high percentages of calcite, and have a lower water content than the natural sediments on which the STP rests.

3. A series of multibeam echosounder data collected between 2013 and 2017 shows that deposition of tailings has triggered several small gravity flows and slides.

4. The tailings within the STP have a low stability compared to the natural sediments outside the STP because of their fine grain-size and higher sensitivity, high slope angles, high sediment accumulation rates preventing normal consolidation, and loading of the tailings causing overpressure in the underlying sediments.

Acknowledgements. This work was performed within the Research Council of Norway's project NYKOS (New knowledge on Sea Disposal, grant number 236658, 80\% funding), co-funded by a consortium of Norwegian Mining Industry Companies (20\% funding). We would like to thank Omya Hustadmarmor and DNV GL for the use of their 2013, 2014 and 2017 multibeam bathymetry data. We are gratefull to the geologist and crew on R/V Seisma, Sigrid Elvenes, John Anders Dahl and Rolf Myhren, for collecting the data in Frænfjorden. Martin Klug is thanked for help in the lab with colour images of the cores. Jan Sverre Laberg and an anonymous reviewer provided valuable comments on the manuscript.

\section{References}

Ai, F., Strasser, M., Preu, B., Hanebuth, T. J. J., Krastel, S. \& Kopf, A. 2014: New constraints on the oceanographic vs. seismic control on submarine landslides initiation: A geotechnical approach off Uruguay and northern Argentina, Geo-Marine Letters 34, 399-417.

Arnesen, R.T., Bjerkeng, B. \& Iversen, E.R. 1997: Comparison of model predicted and measured copper and zinc concentrations at three Norwegian underwater tailings disposal sites. Proceedings of the Fourth International Conference on Acid Rock Drainage, May $31^{\text {st }}$-June $6^{\text {th }}$, Vancouver, B.C. Canada.

Bellwald, B., Hjelstuen, B.O., Sejrup, H.P. \& Haflidason, H. 2016: Postglacial mass movements and depositional environments in a high-latitude fjord system - Hardangerfjorden, Western Norway. Marine Geology 379, 157-175. https://doi.org/10.1016/j.margeo.2016.06.002. 
Bornhold, B.D., Ren, P. \& Prior, D.B. 1994: High-frequency turbidity currents in British Columbia fjords. Geo-Marine Letters 14, 238-243.

Brooks, L., Melsom, F. \& Glette, T. 2015: Biological effects of long term fine limestone tailings discharge in a fjord ecosystem. Marine Pollution Bulletin 96, 321-336.

https://doi.org/10.1016/j.marpolbul.2015.04.052.

Bryhni, I., Austrheim, H. \& Solli, A. 1989: Berggrunnskart Hustad 12201, scale 1:50,000, Norges geologiske undersøkelse.

Bryn, P., Berg, K., Forsberg, C.F., Solheim, A. \& Kvalstad, T. 2005: Explaining the Storegga Slide. Marine and Petroleum Geology 22, 11-19. https://doi.org/10.1016/B978-0-08-044694-3.50005-6.

Burd, B.J., Macdonald, R. \& Boyd, J. 2000: Recovery of sediments and benthic infauna over 15 years following mine tailings deposition in a British Columbia fjord. Marine Environmental Research 49, $145-$ 175. https://doi.org/10.1016/S0141-1136(99)00058-6.

Bøe, R. 1987: Refleksjonsseismiske unders $\emptyset$ kelser i Frænfjorden, Møre og Romsdal. NGU Report 87.095, $11 \mathrm{pp}$.

Bøe, R., Rise, L., Blikra, L.H., Longva, O. \& Eide, A. 2003: Holocene mass movements in Trondheimsfjorden, Central Norway. Norwegian Journal of Geology 83, 3-22.

Bøe, R., Longva, O., Lepland, A., Blikra, L.H., Sønstegaard, E., Haflidason, H., Bryn, P. \& Lien, R. 2004a: Postglacial mass movements and their causes in fjords and lakes in western Norway. Norwegian Journal of Geology 84, 35-55.

Bøe, R., Bugge, T., Rise, L., Eidnes, G., Eide, A. \& Mauring, E. 2004b: Erosional channel incision and the origin of large sediment waves in Trondheimsfjorden, central Norway. Geo-Marine Letters 24, 225-240. https://doi.org/10.1007/s00367-004-0180-3.

Bøe, R., Sandøy, R., Baeten, N.J., Lepland, A., Bellec, V.K., Chand, S., Longva, O., Klug, M., Plassen, L. \& Schönenberger, J. 2018: Marine mine tailings disposal at Lillebukt, Stjernsundet, North Norway: distribution, sedimentary processes and depositional impacts. Norwegian Journal of Geology 98, 461-482. https://doi.org/10.17850/nig98-3-08.

Courtney, B. 2018: NRCAN software. http://ftp.maps.canada.ca/pub/nrcan rncan/raster/ marine geoscience/Seismic Reflection Scanned/tools/ (14.12.2018).

Davies, E.J. \& Nepstad, R. 2017: In situ characterization of complex suspended particulates surrounding an active submarine tailings placement site in a Norwegian fjord. Regional Studies in Marine Science 16, 198-207. https://doi.org/10.1016/i.rsma.2017.09.008.

DNV GL, 2014: Miljøovervåkning Frænfjorden 2013: DNV GL report 2014-0576, 43 pp.

DNV GL, 2016: Miljøovervåking Frænfjorden 2015: Bløtbunnsfauna, sediment- og hydrografiundersøkelse. DNV GL report 2016-0146, 55 pp.

DNV GL, 2017: Miljøovervåking Frænfjorden 2016: DNV GL report 2017-0013, 38 pp.

DNV GL, 2018: Miljøovervåking i Frænfjorden 2017: DNV GL report 114JWI9J-3, 53 pp. 
Ellis, D. \& Ellis, K. 1994: Very deep STD. Marine Pollution Bulletin 28, 472-476.

https://doi.org/10.1016/0025-326X(94)90519-3.

Franks, D.M., Boger, D.V., Côte, C.M. \& Mulligan, D.R. 2011: Sustainable development principles for the disposal of mining and mineral processing wastes. Resources Policy 36, 114-122.

https://doi.org/10.1016/j.resourpol.2010.12.001.

Giurco, D., Dominish, E., Florin, N., Watari, T. \& McLellan, B. 2019: Requirements for Minerals and Metals for $100 \%$ Renewable Scenarios. In Teske, S. (ed.): Achieving the Paris Climate Agreement Goals, Springer Publishing, pp. 437-457. https://doi.org/10.1007/978-3-030-05843-2 11.

Hansen, L., Bøe, R., Sveian, H. \& Husum, K. 2018: Stratigraphic signatures of glacier activity, marine processes and a possible tsunami in the Leirfjorden fjord-valley system, north Norway. Boreas 47, 792-812. https://doi.org/10.1111/bor.12311.

Hjelstuen, B.O., Kjenbakken, H., Bleikli, V., Ersland, R.A., Kvilhaug, S., Euler, C. \& Alvheim, S. 2013: Fjord stratigraphy and processes - evidence from the NE Atlantic Fensfjorden system. Journal of Quaternary Science 28, 421-432. https://doi.org/10.1002/jqs.2636.

Knies, J., Köseoğlu, D., Rise, L., Baeten, N., Bellec, V., Bøe, R., Klug, M., Panieri, G., Jernas, P.E. \& Belt, S. 2018: Nordic Seas polynyas and their role in preconditioning marine productivity during the Last Glacial Maximum. Nature Communications 9. https://doi.org/10.1038/s41467-018-06252-8.

Koski, R.A. 2012: Metal dispersion resulting from mining activities in coastal environments: a pathways approach. Oceanography 25, 170-183. https://doi.org/10.5670/oceanog.2012.53.

Kvalstad, T.J., Andresen, L., Forsberg, C.F., Berg, K., Bryn, P. \& Wangen, M. 2005: The Storegga Slide: Evaluation of triggering sources and slide mechanics. Marine and Petroleum Geology 22, 245-256. https://doi.org/10.1016/B978-0-08-044694-3.50025-1.

Kvassnes, A. \& Iversen, E. 2013: Waste sites from mines in Norwegian Fjords. Mineralproduksjon 3, A27-A38.

Lee, S.H. \& Chough, S.K. 2001: High-resolution (2-7 kHz) acoustic and geometric characters of submarine creep deposits in the South Korea Plateau, East Sea. Sedimentology 48, 629-644. https://doi.org/10.1046/i.1365-3091.2001.00383.x.

Lepland, A., Bøe, R., Lepland, A. \& Totland, O. 2009: Tracking the volume and lateral spread of disposed sediments by acoustic methods, Oslo Harbour, Norway. Journal of Environmental Management 90, 3589-3598. https://doi.org/10.1016/i.jenvman.2009.06.013.

Leynaud, D., Mienert, J. \& Vanneste, M. 2009: Submarine mass movements on glaciated and nonglaciated European continental margins: A review of triggering mechanisms and preconditions to failure. Marine and Petroleum Geology 26, 618-632. https://doi.org/10.1016/j.marpetgeo.2008.02.008.

Nepstad, R., Muñoz, M.L., Alver, M.O., Nordam, T., Davies, E. \& Glette, T. Submitted: High-resolution numerical modelling of a marine tailings discharge in Western Norway.

Norges geologiske undersøkelse 2016: Mineraler for det grønne skiftet. NGU TEMA nr 1, 1-15.

Ramirez-Llodra, E., Trannum, H.C., Evenset, A., Levin, L.A., Andersson, M., Finne, T.E., Hilario, A., Flem, 
B., Christensen, G., Schaanning, M. \& Vanreusel, A. 2015: Submarine and deep-sea mine tailing placements: A review of current practices, environmental issues, natural analogues and knowledge gaps in Norway and internationally. Marine Pollution Bulletin 97, 13-35.

https://doi.org/10.1016/j.marpolbul.2015.05.062.

Rise, L., Bøe, R., Sveian, H., Lyså, A. \& Olsen, H. 2006: The deglaciation history of Trondheimsfjorden and Trondheimsleia, Central Norway. Norwegian Journal of Geology 86, 419-438.

Rise, L. \& Brendryen, J. 2013: Leirinnhold i jordarter - en sammenlignende studie med vekt på metodene Coulter Laser 200 og Sedigraph, og forslag til beregning av ekvivalent leirinnhold i prosent. NGU Report 2013.012, $35 \mathrm{pp}$

Shillington, D., Seeber, L., Sorlien, C.C., Steckler, M.S., Kurt, H., Dondurur, D., Çifçi, G., İmren, C., Cormier, M.H., McHugh, C.M.G., Gürçay, S., Poyraz, D., Okay, S., Atgin, O. \& Diebold, J.B. 2012: Evidence for widespread creep on the flanks of the Sea of Marmara transform basin from marine geophysical data. Geology 40, 439-442. https://doi.org/10.1130/G32652.1.

Shimmield, T.M., Black, K.D., Howe, J.A., Hughes, D.J. \& Sherwin, T. 2010: Final report: Independent Evaluation of Deep-Sea Mine Tailings Placement (DSTP) in PNG. The Scottish Association for Marine Science, Oban, UK, 295 pp.

SINTEF, 2019: New knowledge on Sea disposal.

https://www.sintef.no/globalassets/project/nykos/brosjyre-nykos-standard.pdf (30.05.2019).

Skei, J.M. 2014: Methodologies for Environmental Impact Assessment of Deep Sea Tailings Disposal (DSTP) projects. Proceedings, Impact Assessment for Social and Economic Development 34th Annual Conference of the International Association for Impact Assessment, Vina del Mar, Chile, p 5.

Sultan, N., Cochonat, P., Canals, M., Cattaneo, A., Dennielou, B., Haflidason, H., Laberg, J.S., Long, D., Mienert, J., Trincardi, F., Urgeles, R., Vorren, T.O. \& Wilson, C. 2004: Triggering mechanisms of slope instability processes and sediment failures on continental margins: a geotechnical approach. Marine Geology 213, 291-321. https://doi.org/10.1016/j.margeo.2004.10.011.

Syvitski, P.M., Burrel, D.C. \& Skei, J. 1987: Fjords: processes and products. Springer, Berlin Heidelberg New York, pp. 175-209. https://doi.org/10.1007/978-1-4612-4632-9 5.

Taylor, G. 1953: Dispersion of soluble matter in solvent flowing slowly through a tube. Proceedings Royal Society of London 219, 186-203. https://doi.org/10.1098/rspa.1953.0139.

Vogt, C. 2013: International Assessment of Marine and Riverine Disposal of Mine Tailings. Final Report Adopted by the International Maritime Organization, London Convention/Protocol, IMO, 138 pp.

Wilhelm, B., Nomade, J., Crouzet, C., Litty, C., Sabatier, P., Belle, S., Rolland, Y., Revel, M., Courboulex, F., Arnaud, F. \& Anselmetti, F.S. 2016: Quantified sensitivity of small lake sediments to record historic earthquakes: implications for paleoseismology. Journal of Geophysical Research, Earth Surface 121, 2-16. https://doi.org/10.1002/2015JF003644. 
